\title{
Revised digestive parameter estimates for the Molly cow model
}

\author{
M. D. Hanigan, ${ }^{* 1}$ J. A. D. R. N. Appuhamy, ${ }^{*}$ and P. Gregorini† \\ *Department of Dairy Science, Virginia Polytechnic Institute and State University, Blacksburg 24061 \\ †DairyNZ Ltd., Private Bag 3221, Hamilton 3240, New Zealand
}

\section{ABSTRACT}

The Molly cow model represents nutrient digestion and metabolism based on a mechanistic representation of the key biological elements. Digestive parameters were derived ad hoc from literature observations or were assumed. Preliminary work determined that several of these parameters did not represent the true relationships. The current work was undertaken to derive ruminal and postruminal digestive parameters and to use a meta-approach to assess the effects of interactions among nutrients and identify areas of model weakness. Model predictions were compared with a database of literature observations containing 233 treatment means. Mean square prediction errors were assessed to characterize model performance. Ruminal $\mathrm{pH}$ prediction equations had substantial mean bias, which caused problems in fiber digestion and microbial growth predictions. The $\mathrm{pH}$ prediction equation was reparameterized simultaneously with the several ruminal and postruminal digestion parameters, resulting in more realistic parameter estimates for ruminal fiber digestion, and moderate reductions in prediction errors for $\mathrm{pH}$, neutral detergent fiber, acid detergent fiber, and microbial $\mathrm{N}$ outflow from the rumen; and postruminal digestion of neutral detergent fiber, acid detergent fiber, and protein. Prediction errors are still large for ruminal ammonia and outflow of starch from the rumen. The gain in microbial efficiency associated with fat feeding was found to be more than twice the original estimate, but in contrast to prior assumptions, fat feeding did not exert negative effects on fiber and protein degradation in the rumen. Microbial responses to ruminal ammonia concentrations were half saturated at $0.2 \mathrm{~m} M$ versus the original estimate of $1.2 \mathrm{mM}$. Residuals analyses indicated that additional progress could be made in predicting microbial $\mathrm{N}$ outflow, volatile fatty acid production and concentrations, and cycling of $\mathrm{N}$ between blood and the rumen. These additional corrections should lead to an even more robust representation of

Received September 21, 2012.

Accepted February 9, 2013.

${ }^{1}$ Corresponding author: mhanigan@vt.edu the effects of dietary nutrients on ruminal metabolism and nutrient absorption, of animal performance, and the environmental impact of dairy production.

Key words: bovine, metabolism, digestion, model

\section{INTRODUCTION}

Accurate and precise models relating dietary inputs and animal performance are required to devise feeding strategies that minimize feed costs while maximizing animal performance and minimizing the environmental impact (Gregorini et al., 2010). A variety of nutrient requirement models have been developed over time to address this challenge (AFRC, 1993, 1998; NRC, 1978, 1984, 2001). These models can be adapted to simultaneously consider nutrient requirements and environmental loading (Hadrich et al., 2008), although this is limited to nutrients considered by the models. However, given the static nature of these models, it will not be easy to modify them to consider other management strategies that are time dependent, such as feeding frequency, supplementation timing, grazing methods, and reproductive management, among others (Beukes et al., 2010, 2011).

Mechanistic models such as Molly (Baldwin et al., 1987a,b,c; Danfær, 1990; Dijkstra et al., 1992) offer several potential benefits, including the ability to represent interactions between the animal and digestive processes, the ability to represent more processes that can be tested against empirical data and serves to integrate knowledge, and, in the case of the above dynamic models, the ability to represent time-dependent processes. Molly also offers the opportunity to predict directly most of the animal-related factors that affect the environment, including methane, $\mathrm{CO}_{2}$, urinary urea, and fecal N. However, increased complexity increases the number of equations that must be parameterized. Unlike the above nutrient requirement models, Molly has not been subjected to extensive efforts to derive robust parameter estimates associated with the various digestive and metabolic processes considered in the model.

Digestion parameters in Molly were previously derived using data from the literature (Hanigan et al., 2009). Although these parameters were much better 
than the original parameters derived by Baldwin et al. $(1987 \mathrm{a}, \mathrm{b}, \mathrm{c})$, the prediction errors for ruminal $\mathrm{pH}$, ammonia and VFA concentrations, and lipid and microbial N flow were biased (Hanigan et al., 2009 and subsequent unpublished work).

For these prior analyses, nutrient analyses of ingredients were used when available and missing values were filled with tabular NRC values to achieve a full nutrient profile. This approach can lead to potential bias when predicting dietary nutrients and may have contributed to the observed model prediction bias (Hanigan et al., 2009). Another limitation with the prior work was that ruminal $\mathrm{pH}$ was underpredicted by approximately 0.5 $\mathrm{U}$, which depressed microbial activity. This could have contributed to the observed biases in VFA concentrations.

It was hypothesized that rederivation of ruminal $\mathrm{pH}$, digestion, and microbial growth parameters in the Molly cow model, while attempting to accommodate potential nutrient input bias, would result in more accurate and precise predictions of ruminal digestion and nutrient outflow from the rumen and postruminal nutrient digestion than the current model. The objective of the current work was to use a data set constructed from the literature to solve for a set of parameters that resulted in unbiased predictions of ruminal $\mathrm{pH}$, ruminal nutrient degradation, microbial growth, and postruminal digestion.

\section{MATERIALS AND METHODS}

The model used was that of Baldwin et al. (1987a,b,c), with modifications described by Baldwin (1995) and Hanigan et al. (2006, 2007, 2009). Simulations were conducted with ACSL Math software (version 2.5.4; AEgis Technologies Group Inc., Huntsville, AL). The model was set to use observed DMI, to consume feed at a constant rate, to predict ruminal liquid volume from ruminal DM mass, to milk out twice daily, and to use the VFA stoichiometry set for a mixed forage and concentrate diet (Argyle and Baldwin, 1988) for all observations, which reflected the nature of the diets in the database used. The model was set to run $21 \mathrm{~d}$ before comparisons with observed data were made to ensure that it had reached steady-state conditions.

Data used for model reparameterization were assembled from the literature and represented 62 experiments with 233 treatment means (Hanigan et al., 2006). A list of the references is provided in Table 1, and a summary of the data are provided in Table 2. The data are a subset of those used by the NRC committee to formulate the 2001 nutrient requirement model (NRC, 2001). Of the 62 experiments, 3 were conducted with nonlactating heifers and the remainder with lactating cows. Four manuscripts did not report the breed of animal used, of which 3 were subsequently determined to have used Holsteins. One study used Swedish Red, 1 used Friesians, and the remainder used Holstein-Friesians.

Initial BW were set to match those reported in the literature. If no value was reported, the model was set to an initial BW of $600 \mathrm{~kg}$. A BCS of 3.4 (scale 1 to 5 ) was assumed for all observations. Although it had no bearing on digestive predictions, starting DIM was set to a value of $21 \mathrm{~d}$ before the reported values so that DIM matched the observed days after the model was run $21 \mathrm{~d}$. In no case did this result in a model starting point before calving. If DIM were not reported, it was set to 70 .

Table 1. A listing of references for the experimental data used for model evaluations and parameter estimation

\begin{tabular}{lll}
\hline Aldrich et al. (1993) & Klusmeyer et al. (1991b) & Prange et al. (1984) \\
Armentano et al. (1986) & Kung et al. (1983) & Price et al. (1988) \\
Blauwiekel et al. (1997) & Lu et al. (1988) & Putnam et al. (1997) \\
Calsamiglia et al. (1995) & Lykos and Varga (1997) & Robinson and Sniffen (1985) \\
Cameron et al. (1991) & Lykos et al. (1997) & Sobinson et al. (1997) \\
Chan et al. (1997) & Lynch et al. (1991) & Sarwar et al. (1991) \\
Christensen et al. (1993) & Mabjeesh et al. (1996) & Schwab et al. (1992a) \\
Cunningham et al. (1994) & Mabjeesh et al. (1997) & Schwab et al. (1992b) \\
Cunningham et al. (1996) & Mansfield and Stern (1994) & Seymour et al. (1992) \\
Doreau et al. (1991) & McCarthy et al. (1989) & Song and Kennelly (1989) \\
Erasmus et al. (1994) & Merchen and Satter (1983) & Stokes et al. (1991) \\
Espindola et al. (1997) & Murphy et al. (1987) & Tice et al. (1993) \\
Feng et al. (1993) & Narasimhalu et al. (1989) & Waltz et al. (1989) \\
Herrera-Saldana et al. (1990) & Ohajuruka et al. (1991) & Windschitl and Stern (1988) \\
Horner et al. (1988) & Oliveira et al. (1995) & Yang et al. (1997) \\
Joy et al. (1997) & O'Mara et al. (1997) & Yoon and Stern (1996) \\
Kalscheur et al. (1997a) & Overton et al. (1995) & Zerbini et al. (1988) \\
Kalscheur et al. (1997b) & Pantoja et al. (1995) & Zhu et al. (1997) \\
King et al. (1990) & Pena et al. (1986) & \\
Klusmeyer et al. (1990) & Pires et al. (1997) & \\
Klusmeyer et al. (1991a) & Poore et al. (1993) & \\
\hline
\end{tabular}


Table 2. A summary of the data contained in references listed in Table 1 and used for model evaluations and parameter estimation

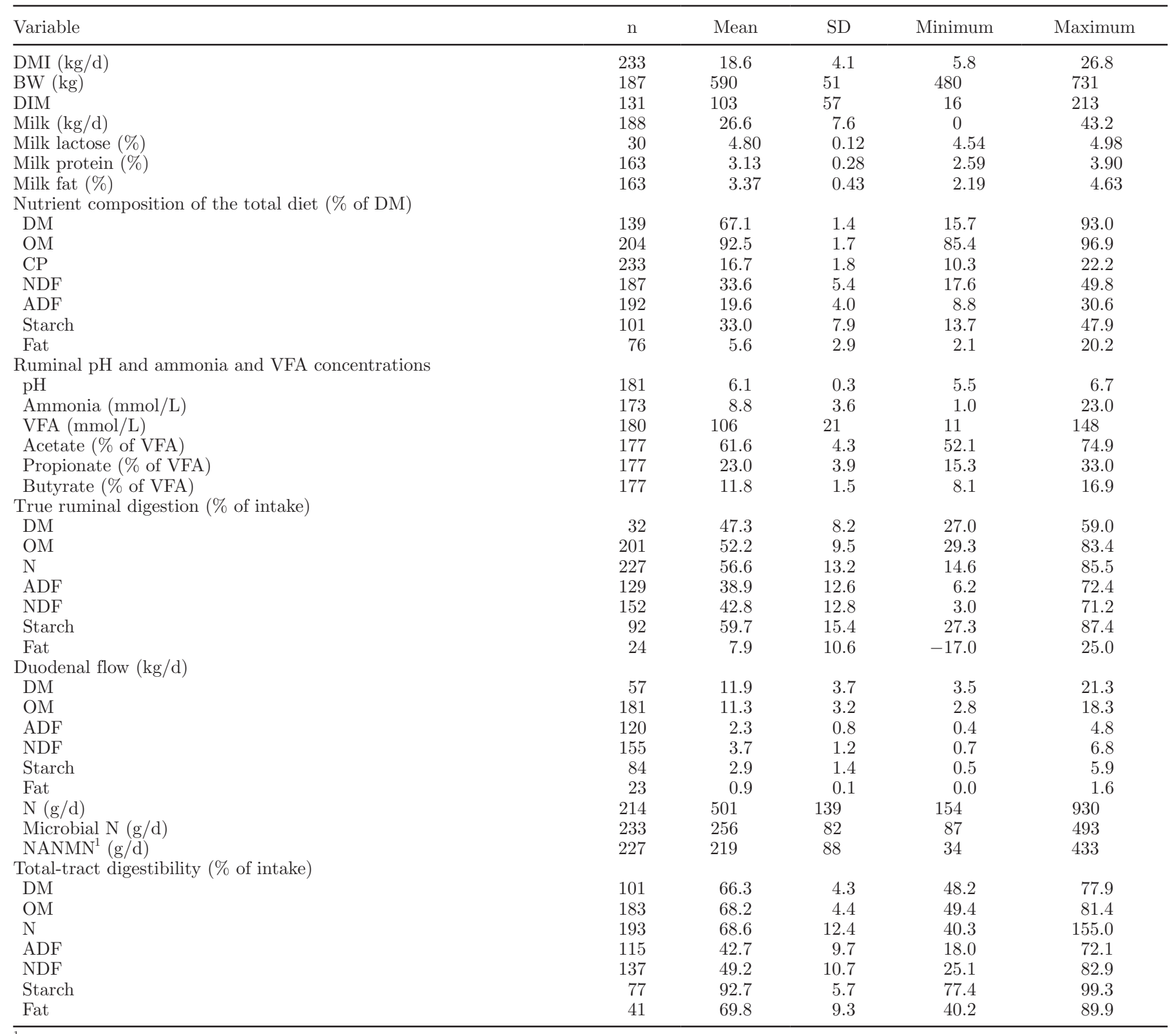

${ }^{1}$ Nonammonia, nonmicrobial N.

Primary nutrient inputs required by the model include $\mathrm{CP}$, fat, starch, ADF, NDF, lignin, and ash, all expressed as a proportion of DM. Carbohydrate composition was further characterized with inputs of soluble starch, ruminally undegraded starch, ruminally undegraded ADF, and forage NDF, all expressed as a percentage of the parent material. Protein composition was characterized with inputs of soluble protein, RUP, NPN, and urea all expressed (in CP units) as a percentage of CP. Expressing carbohydrate and protein composition as a percentage of the parent material is a deviation from the original input description of Hani- gan et al. (2006). Nonprotein nitrogen was assumed to represent NPN and non-urea sources such as nucleic acids. Contrary to some categorization schemes, free amino acids and peptides found in grasses and silages are represented as soluble protein rather than NPN. Urea was also specified separately due to its low carbon content, consistent with the original description of inputs (Baldwin, 1995).

If nutrient composition of individual ingredients was reported, which was generally the case with forages, those values were used in calculating dietary nutrients. Missing nutrients were generated from tabular values 
Table 3. A summary of bias adjustments applied to predicted dietary nutrients

\begin{tabular}{lcccrc}
\hline Item & Starch & CP & ADF & NDF & Fat \\
\hline $\mathrm{n}^{1}$ & 96 & 225 & 181 & 177 & 75 \\
Mean bias (\% of DM) & -1.35 & 0.23 & -0.28 & 2.03 & 0.00 \\
Minimum bias (\% of DM) & -12.52 & -2.76 & -9.37 & -10.68 & -0.02 \\
Maximum bias (\% of DM) & 10.48 & 5.84 & 10.83 & 8.15 & 0.06 \\
RMSPE $^{2}(\%)$ & 19.5 & 10.5 & 18.4 & 14.9 & 49.4 \\
Bias-adjusted RMSPE $^{3}(\%)$ & 15.1 & 5.7 & 11.7 & 8.7 & 34.2 \\
Error reduction (\%) & 22.4 & 45.2 & 36.3 & 41.2 & 30.8 \\
\hline${ }^{1}$ Represents the number of individual treatment means used for bias calculations. \\
${ }^{2}$ Root mean square prediction error (RMSPE) = error of prediction when using ingredient values to predict \\
complete diet values. \\
${ }^{3}$ Error of prediction when using ingredient values to predict complete diet values after bias correction.
\end{tabular}

(NRC, 2001) in the following manner: starch content of individual ingredients was calculated as $80 \%$ of the ingredient NFC value, which is equivalent to total dietary ratios for common feeding programs (Batajoo and Shaver, 1994). Soluble starch (SolStarch) was assumed to be $20 \%$ of total starch, which reflects the high proportion of maize grain in most of the diets (Batajoo and Shaver, 1998). Ruminally undegraded starch (RuStarch) was calculated as follows:

$$
\text { RuStarch }=(\text { Starch }- \text { SolStarch }) \times 0.631,
$$

where 0.631 represented the mean proportion of insoluble starch appearing at the duodenum for the entire data set. The difference between SolStarch and RuStarch represents the insoluble but ruminally degraded fraction. Ruminally undegraded ADF (RuADF) was calculated as follows:

$$
\mathrm{RuADF}=\mathrm{ADF} \times 0.405,
$$

where 0.405 represented the mean observed proportion of intake ADF appearing at the duodenum.

Because diets were reconstructed from individual ingredients using a mix of tabular and observed values, potential for bias exists in the predicted dietary nutrient inputs to the model associated with the use of the tabular values. Such bias would translate into biased model parameter estimates if not corrected. For example, if dietary protein intakes were overestimated, then the ruminal protein degradation rate constant would have to assume a larger-than-appropriate value to bring protein outflow from the rumen in line with the, presumably, unbiased estimates of undegraded feed protein outflow. For this reason, it is critical to try to remove bias in feed inputs. For starch, protein, ADF, $\mathrm{NDF}$, and fat, the predicted dietary concentrations as calculated from summation of the individual dietary ingredients were compared with the observed dietary concentrations when available and mean bias within experiment was determined and used to correct the predicted values so that they aligned with the observed dietary values. This was achieved by determining the mean bias $[\Sigma($ observed - predicted $) / \mathrm{N}]$ across treatments within an experiment and adding that value to the model-calculated nutrient values for each diet in that study. Bias factors were developed for starch, CP, ADF, NDF, and fat. A summary of the dietary bias adjustments are presented in Table 3. Unfortunately adjustments could not be developed for other nutrients, as dietary values were not reported in the literature.

Soluble carbohydrate (SolCHO; \% of DM) was calculated on a dietary basis from dietary NFC and starch after bias adjustment:

$$
\text { SolCHO }=\text { NFC }- \text { Starch } .
$$

If SolCHO was less than 0, it was assumed to be 0 , and the difference from 0 was subtracted from dietary starch. Because this adjustment was applied after calculation of SolStarch, it effectively assumes that any overestimate of NFC is due to an overestimate of insoluble starch.

Ruminally undegraded $\mathrm{CP}$, starch, and ADF were then used to calculate ruminal degradation rate parameters for insoluble protein, starch, and cellulose, assuming a mean ruminal residence time (RRT) in the small particle pool of $8 \mathrm{~h}$ for starch and protein and 18 $\mathrm{h}$ for ADF (Hanigan et al., 2006). The rate constant for hemicellulose was calculated as a proportion of the cellulose rate constant as originally described (Baldwin, 1995).

It was assumed that ruminally undegraded nutrient fractions, as determined from in sacco analyses, provided an accurate representation of the relative differences in rates of ruminal degradation among feeds, which has been demonstrated for protein (Madsen and Hvelplund, 1985). Use of the observed mean fractions of starch and ADF escaping the rumen in Equations 1 and 2 ensures that the relative differences among ingredients and 
diets will be centered around the true observed mean escape. However, the absolute rate of degradation, as determined in sacco, may still be biased relative to the model structure where, among other things, nutrient passage from the rumen is represented. Thus, for datafitting purposes, an adjustable variable $\left(F_{X} ; \mathrm{d}^{-1}\right)$ was introduced into all 3 rate parameter calculations (ADF, protein, and starch), yielding the following modified rate parameter calculation equation:

$$
\begin{aligned}
& K_{\text {DegX }}\left(\mathrm{d}^{-1}\right) \\
& =\frac{24}{\mathrm{RRT}} \times-\ln \left[f_{\text {RumUndeg }, F d} /\left(f_{\text {Total }, F d}-f_{\text {SolX }, F d}\right)\right]+F_{X},
\end{aligned}
$$

where $K_{\text {DegX }}, f_{\text {RumUndegX,Fd }}, f_{\text {TotalX,Fd }}$, and $f_{\text {SolX,Fd }}$ represented the rate constant for ruminal degradation of nutrient $\mathrm{X}$, the fractional proportion of ruminally undegraded nutrient $\mathrm{X}$ in feed, the fractional proportion of total nutrient $\mathrm{X}$ in feed, and the fractional proportion of soluble nutrient $\mathrm{X}$ in feed, respectively, where $\mathrm{X}$ represented starch, protein, and ADF (ADF was used to calculate the rate of degradation of cellulose directly and hemicellulose indirectly). The variable $F_{X}$ was initially set to 0 and derived by fitting to the observed digestive nutrient flow data for nutrient X. The ratio 24/RRT represented the time conversion from the assumed 8-h residence time to a daily rate to be consistent with time units in the model. Again, using a residence time greater than 8 $\mathrm{h}$ would not appreciably change the relative differences across ingredients in calculated rates of degradation; however, it would result in a different solution for $F_{X}$.

Having defined all of the dietary nutrient and animal inputs required by the model, key ruminal and postruminal digestive parameters were estimated by fitting model predictions of ruminal $\mathrm{pH}$, ammonia, and VFA concentration; ruminal outflow of DM, NDF, ADF, starch, lipid, total $\mathrm{N}$, microbial $\mathrm{N}$, and nonammonia, nonmicrobial N (NANMN); and fecal flows of NDF, $\mathrm{ADF}$, starch, lipid, and $\mathrm{N}$ to observed values using the Nelder-Mead optimization algorithm (Press, 2007) within ACSL Math to maximize the log-likelihood function (LLF). Parameters to be fitted were identified through examination of the driving variables in the equations used to predict the outputs and by sensitivity analyses. In general, minimum and maximum bounds of 0.5 and 2 times the starting parameter estimate were used for fitting. These were adjusted each time an optimization run was initiated to maintain that general relationship with the current parameters estimates which ensured that none of the final parameter estimates were resting against or approaching a bound. The exception was that for most parameters, a lower bound of 0 was maintained, as negative values were not biologically possible. Because of the size of the problem, the ruminal parameters were derived as a set first, and having fixed those parameters, the postruminal parameters were derived as a separate set. This prevented introduction of bias into, for example, postruminal predictions to minimize an opposite bias in ruminal predictions. Root mean square prediction errors (MSPE) and partitioning of MSPE into mean and slope bias was also conducted as described by Bibby and Toutenburg (1977) using the scripting language in ACSL Math.

Two independent efforts were undertaken to consider experiment effects during parameter estimation. In the first case, the LLF calculation was altered to calculate the mean deviation for each experiment and adjust the residuals for individual experiment deviations before calculation of the LLF. This approach ensured that only within-experiment responses influenced parameter estimation, consistent with the goals of a meta-analysis (St-Pierre, 2001). However, this approach proved nonviable, as the modified algorithms could not solve for a known set of digestion parameters and known experiment deviations when fitted to a set of data simulated using those digestion and experimental bias parameters.

The second approach involved coding a vector of bias factors $\left(\varnothing_{j}\right.$, where $j$ represented the experiment number) for each predicted output variable. These individual bias-adjustment factors were added to the modelpredicted output variable $\left(\hat{Y}_{i j}\right.$, where $i$ represented individual treatment means) to create a set of unbiased model predictions $\left(\hat{\Psi}_{i j}\right)$, which were compared with the observed data $\left(\right.$ residual $\left._{i j}=\operatorname{observed}_{i j}-\hat{\Psi}_{i j}\right)$. In other words, the model predictions were bias corrected before calculation of residuals:

$$
\hat{\Psi}_{i j}=\hat{Y}_{i j}+\varnothing_{j}
$$

Thus, $\varnothing$ acts as a fixed set of intercept adjustments forcing the common slope to be derived from withinexperiment observations (Figure 1$) ; \varnothing_{j}$ were initially set to 0 (no experiment bias), and included as adjustable parameters in the optimization run. The only difference between this approach and the prior one is that these parameters were estimated explicitly and, thus, were part of the parameter variance structure during the optimization run. This approach resulted in huge arrays of adjustable variables (a few model parameters plus an intercept for each experiment for each output variable) that required massive amounts of computing time for solutions and hampered the ability of the optimizers to reach a global solution. Repeated restarts 
using parameter estimates from the prior run as the starting point for the next run resulted in an LLF value that reached a plateau after 4 or 5 starts. Although this approach likely resulted in better within-experiment parameter estimates, some of the derived digestion coefficients deviated substantially from estimates where experiment effects were not considered, which coincided with a large range in $\varnothing_{j}$. By example, if the within-experiment slope is considerably less than the global slope (across experiments), the range in experiment intercepts would have to be large for the predicted values to remain within the range of observed data (Figure 1). Use of the derived within-experiment slope and an average experiment adjustment value $(\bar{\varnothing})$ results in overprediction of responses at very low inputs relative to observed values and underprediction at very high inputs when the within-experiment slope is less than the global slope. Unless $\varnothing_{j}$ can be predicted (i.e., the underlying cause of $\varnothing_{j}$ is represented), the derived model will do a very poor job of predicting throughout the data range.

It seemed likely that some of the apparent experiment effects could be caused by interactions among nutrients that were not adequately represented in the model. For example, if one experiment had dietary NDF much greater than the mean and another much less, and NDF was influencing digestive processes, residual errors from the model would present as random experiment effects if the model did not adequately represent those interactions. The residuals would also correlate with dietary NDF. Because of the potential for experiment effects to cloud the relationship between NDF, in this example, and residual errors, a post hoc analysis of residuals was

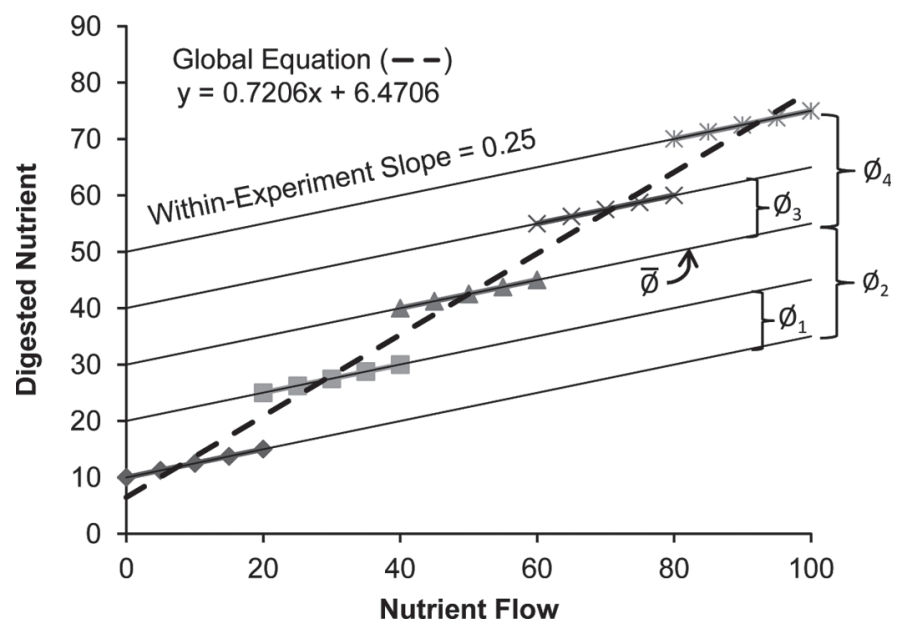

Figure 1. Example of fixed effects in digestion data. $\varnothing_{i}$ represents the effect of individual experiment and $\bar{\varnothing}$ represents the mean experimental effect. The global equation describes the response across experiments. adopted that included experiment effects as a method to identify model elements that were missing or not properly represented. Analyses were conducted using backward elimination regression, with experiment included as a random class variable to identify potential factors affecting prediction accuracy. Residuals were regressed on observed DMI, dietary nutrient intakes, and DIM, and predicted $\mathrm{BW}$, ruminal $\mathrm{pH}$, and ruminal ammonia concentrations to determine relationships with key model inputs and driving model variables ( $\mathrm{pH}$ and ammonia). When examining residual errors for predictions of ruminal $\mathrm{pH}$ or ammonia, they were not included in the regression model as independent variables. Variables were removed from the model if the associated $P$-value was greater than 0.10 . Initial results from this work resulted in the addition of the parameters encoding fat and ammonia effects on microbial growth and fat effects on fiber and starch degradation to the optimization parameter set.

Global sensitivity of ruminal $\mathrm{pH}$, ruminal VFA concentrations, ruminal ammonia concentrations, and outflow of microbial nitrogen and undegraded feed nutrients from the rumen to ruminal model parameters was undertaken using the Fourier amplitude sensitivity test provided in acslX software (version 3.1; AEgis Technologies Group Inc.) as described by Saltelli et al. (1999). The parameters were sampled using boundaries of 70 and $130 \%$ of the final parameter estimates, except for the constant for the effect of fat on fiber digestion $\left(K_{F a t H b} ; \mathrm{g}\right.$ of endogenous fat/g of added fat) and the constant for the effect of fat on protein digestion ( $K_{\text {FatP }} ;$ g of endogenous fat/g of added fat), which were set to the much wider bounds of 0 and 0.01 to reflect the uncertainty regarding their inclusion in the model. Resampling was set to 4 and the interference factor was set to 4 . These settings resulted in a sampling population of 204,792 runs from which the global sensitivity coefficients were derived. All statistical summaries of the observed data and regression analyses were conducted using PROC MEANS, GLM, and MIXED of SAS (version 9.1; SAS Institute Inc., Cary, NC).

\section{RESULTS AND DISCUSSION}

\section{Feed Inputs}

It was apparent from the residuals analyses of dietary nutrient predictions that the use of tabular nutrient values for individual ingredients to supplement the incomplete observed ingredient data resulted in biased predictions if no adjustments were applied (Table 3). Without bias adjustment, mean bias (\% of dietary DM) for starch, CP, NDF, ADF, and fat was $-1.35,0.23$, $2.03,-0.28$, and 0 , respectively, where negative values 
denote overpredictions and positive values underpredictions. Of course, the range in bias was much greater than the mean, indicating that dietary inputs for some studies deviated even more from observed values in the absence of a correction. Applying within-study bias corrections where dietary nutrient concentrations were reported reduced prediction errors for dietary starch, $\mathrm{CP}, \mathrm{ADF}, \mathrm{NDF}$, and fat from 22 to $45 \%$, depending on the nutrient. Assuming the observed dietary nutrients were accurate representations of the true diet, using correction factors to adjust dietary inputs so they matched observed inputs resulted in reduced input variation, which should lead to more accurate estimates of digestion parameters. Unfortunately no studies reported the full range of dietary nutrients required by the model and many studies did not report even this limited set of nutrients. In those cases, no corrections could be made, and based on the observations from studies that reported data, it seems likely that some bias may still remain in nutrient intake predictions.

\section{Nutrient Digestion and Ruminal Metabolism}

An evaluation of prediction errors for the initial model (Hanigan et al., 2009) was conducted to assess model performance with bias-adjusted nutrient inputs (Table 4). Some minor differences existed compared with the prior evaluation using this data set (Hanigan et al., 2006) that were associated with these adjustments; however, the results were generally consistent. Predictions exhibiting prediction errors greater than $20 \%$ included ruminal ammonia and VFA concentrations, the proportion of VFA as propionate, passage of all nutrients and microbial protein to the small intestine, and lower-tract digestion of ADF and NDF. Ammonia, molar proportions of all $3 \mathrm{VFA}$, lipid passage, and intestinal ADF digestibility also exhibited substantial proportions of the prediction error as slope bias. Total $\mathrm{N}$ and microbial $\mathrm{N}$ passage exhibited substantial proportions of error as mean bias.

Although ruminal $\mathrm{pH}$ values had relatively low prediction errors, essentially all of the error was due to mean bias associated with an underprediction by approximately $0.5 \mathrm{pH}$ units. This is problematic, as microbial activity predictions are dependent upon ruminal pH (Argyle and Baldwin, 1988). Underpredicting $\mathrm{pH}$ by 0.5 results in significant depression in predictions of microbial growth and metabolism, which affect essentially all of the ruminal output predictions, as evidenced by the sensitivity of those outputs to $\mathrm{pH}$ prediction equation parameters (Table 5).

The model predicts $\mathrm{pH}$ from total VFA concentrations using an adaptation of the equation of Briggs et al. (1957) as described by Argyle and Baldwin (1988). Using just the observed data, the validity of that prediction equation was checked by regressing observed $\mathrm{pH}$ on observed VFA concentrations. The resulting equation had an intercept of $6.50 \pm 0.10$ and a VFA coefficient of $-3.62 \pm 0.88 \mathrm{~mol}^{-1}\left(P<0.0001, \mathrm{R}^{2}=0.10\right)$ as compared with 7.2 and $-10.0 \mathrm{~mol}^{-1}$, respectively in the equation of Briggs et al. (1957). Addition of an ammonia term to the regression model as in the original work did not result in a significant improvement $(P$ $>0.05$ ) and, thus, does not explain the difference in the relationships. As the original work was conducted with data from sheep, it seems likely that the substantial differences in the relationships are due to species differences and suggests that this equation has been problematic since its adoption some $24 \mathrm{yr}$ ago.

Having identified the model predictions that were biased, an iterative series of parameter estimations was undertaken, which was followed by residual analyses (with consideration of experiment effects) in an attempt to correct the observed problems. The final parameter estimates resulting from this series are presented in Table 6. In general, the parameters were well defined by the data, as reflected by relatively small standard deviations for the parameter estimates. Although the model is highly integrative, the correlations among ruminal parameters were relatively low, with most having correlations of less than 0.2 (Table 7 ). Exceptions were the slope for the VFA effect on $\mathrm{pH}\left(K_{p H V F A} ; \mathrm{mol}^{-1}\right)$ and the rate constant for ammonia absorption $\left(K_{A m A b s}\right.$; $-0.252)$, the intercept for $\mathrm{pH}$ prediction $\left(\right.$ Int $\left._{p H}\right)$ and the scalar for the cellulose degradation rate constant calculation $\left(F_{K R u A D F} ;-0.227\right), F_{K R u A D F}$ and the scalar for the protein degradation rate constant calculation $\left(F_{K R U P} ;-0.221\right)$, the constant to calculate the effect of fat on microbial growth $\left(K_{F a t F G}\right.$; g of DM/g of dietary fat) and the rate constant for propionate absorption $\left(K_{A b s P r} ;-0.215\right)$, and $K_{p H V F A}$ and the rate constant for acetate absorption $\left(K_{A b s A c} ;-0.204\right)$. Given the independence of postruminal nutrient flows, it was surprising that intestinal starch, fiber, and fat digestibilities were relatively highly correlated, with coefficients of 0.57 for the intestinal digestion coefficient for starch $\left(K_{\text {Starch.LGut }}\right.$; $\mathrm{g} / \mathrm{g}$ ) and the intestinal digestion coefficient for lipid ( $K_{\text {Lipid,LGut }} ; \mathrm{g} / \mathrm{g}$ ), 0.685 for $K_{\text {Lipid,LGut }}$, and the intestinal digestion coefficient for fiber $\left(K_{F i b e r, L G u t}\right)$, and 0.613 for $K_{\text {Starch,LGut }}$ and $K_{\text {Fiber,LGut }}$. Correlation coefficients for the intestinal digestion coefficient for protein $\left(K_{\text {Protein,LGut }}\right)$ with $K_{\text {Starch,LGut }}, K_{\text {Fiber,LGut }}$, and $K_{\text {Lipid,LGut }}$ were 0.145 , 0.054 , and 0.005 , respectively (data not shown). The greater correlations may have been an artifact of fitting to fecal NDF and ADF, which are correlated due to the common subnutrients within those fiber fractions. 
Table 4. Residual error analyses for predictions by Molly with parameter estimates of Hanigan et al. (2009; initial) and the parameters listed in Table 6 (final) ${ }^{1}$

\begin{tabular}{|c|c|c|c|c|c|c|c|c|c|c|}
\hline \multirow[b]{2}{*}{ Variable } & \multirow[b]{2}{*}{$\mathrm{n}$} & \multirow{2}{*}{$\begin{array}{l}\text { Observed } \\
\text { mean }\end{array}$} & \multicolumn{2}{|c|}{ Predicted mean } & \multicolumn{2}{|c|}{$\begin{array}{c}\text { RMSPE }^{2} \\
\text { (\% of observed) }\end{array}$} & \multicolumn{2}{|c|}{$\begin{array}{l}\text { Mean bias } \\
(\% \text { of MSPE) }\end{array}$} & \multicolumn{2}{|c|}{$\begin{array}{l}\text { Slope bias } \\
\text { (\% of MSPE) }\end{array}$} \\
\hline & & & Initial & Final & Initial & Final & Initial & Final & Initial & Final \\
\hline \multicolumn{11}{|l|}{ Ruminal metabolism } \\
\hline $\mathrm{pH}$ & 166 & 6.12 & 5.74 & 6.11 & 7 & 4 & 69 & 0.1 & 1 & 0.4 \\
\hline Ammonia (mmol/L) & 159 & 8.53 & 7.60 & 6.02 & 59 & 67 & 5 & 20 & 47 & 43 \\
\hline $\mathrm{VFA}(\mathrm{mmol} / \mathrm{L})$ & 164 & 106 & 97 & 106 & 22 & 21 & 15 & 0.0 & 1 & 7 \\
\hline Acetate ( $\%$ of VFA) & 161 & 61.8 & 62.9 & 63.7 & 9 & 8 & 6 & 14 & 26 & 13 \\
\hline Propionate ( $\%$ of VFA) & 161 & 22.9 & 25.0 & 24.3 & 20 & 19 & 18 & 10 & 14 & 4 \\
\hline Butyrate ( $\%$ of VFA) & 161 & 11.8 & 12.1 & 12.0 & 15 & 14 & 2 & 1 & 31 & 21 \\
\hline \multicolumn{11}{|l|}{ Ruminal outflow (kg/d) } \\
\hline $\mathrm{DM}$ & 47 & 12.8 & 11.76 & 12.4 & 16 & 15 & 6 & 5 & 22 & 9 \\
\hline $\mathrm{NDF}$ & 133 & 3.82 & 4.08 & 3.77 & 28 & 26 & 11 & 0.2 & 3 & 5 \\
\hline $\mathrm{ADF}$ & 104 & 2.37 & 2.35 & 2.41 & 25 & 23 & 0.01 & 0.5 & 2 & 1 \\
\hline Starch & 78 & 2.84 & 2.90 & 3.13 & 40 & 41 & 0.01 & 6 & 7 & 8 \\
\hline Lipid & 23 & 0.98 & 0.97 & 1.0 & 23 & 23 & 0.2 & 1 & 24 & 25 \\
\hline Nitrogen $(g / d)$ & 199 & 499 & 433 & 477 & 23 & 19 & 38 & 9 & 0.2 & 2 \\
\hline Microbial N (g/d) & 211 & 258 & 218 & 266 & 30 & 27 & 26 & 1 & 0.001 & 2 \\
\hline $\operatorname{NANMN}^{3}(\mathrm{~g} / \mathrm{d})$ & 211 & 218 & 212 & 209 & 33 & 35 & 1 & 2 & 6 & 8 \\
\hline \multicolumn{11}{|c|}{ Postruminal digestion ( $\mathrm{g} / \mathrm{g}$ of flow) } \\
\hline $\mathrm{NDF}$ & 131 & 0.483 & 0.428 & 0.479 & 26 & 22 & 22 & 1 & 13 & 4 \\
\hline $\mathrm{ADF}$ & 108 & 0.424 & 0.446 & 0.436 & 28 & 22 & 4 & 2 & 38 & 6 \\
\hline Starch & 75 & 0.924 & 0.934 & 0.926 & 6 & 6 & 2 & 0.01 & 6 & 2 \\
\hline Lipid & 41 & 0.721 & 0.694 & 0.698 & 13 & 13 & 0.3 & 0.1 & 1 & 2 \\
\hline Protein & 183 & 0.686 & 0.694 & 0.668 & 19 & 9 & 0.5 & 0.004 & 5 & 13 \\
\hline
\end{tabular}

Dietary nutrients were adjusted to remove mean bias across diets within an experiment using the bias-adjustment factors summarized in Table 3 .

${ }^{2}$ Root mean square prediction error (MSPE).

${ }^{3}$ Nonammonia, nonmicrobial N. 
Table 5. Global analyses of the sensitivity of model digestive predictions to digestive parameters ${ }^{1}$

\begin{tabular}{|c|c|c|c|c|c|c|c|c|c|c|c|c|c|c|c|c|c|c|c|}
\hline \multirow{3}{*}{$\begin{array}{l}\text { Model } \\
\text { parameter }^{2}\end{array}$} & \multicolumn{19}{|c|}{ Predicted model output $^{3}$} \\
\hline & \multirow[b]{2}{*}{$\mathrm{pH}$} & \multicolumn{2}{|c|}{ Concentration } & \multicolumn{3}{|c|}{ Molar proportion } & \multicolumn{8}{|c|}{ Ruminal outflow } & \multicolumn{5}{|c|}{ Fecal output } \\
\hline & & $\mathrm{Am}$ & VFA & $\mathrm{Ac}$ & $\operatorname{Pr}$ & $\mathrm{Bu}$ & DMP & NDFP & ADFP & $\mathrm{HaP}$ & LipidP & NitP & MiNP & NANMNP & Starch & $\mathrm{NDF}$ & $\mathrm{ADF}$ & Protein & Lipid \\
\hline \multicolumn{20}{|c|}{ Ruminal (proportion of total variation) } \\
\hline$K_{A m A b s}$ & 0.001 & 0.431 & 0.001 & 0.001 & 0.001 & 0.001 & 0.001 & 0.001 & 0.001 & 0.001 & 0.001 & 0.004 & 0.002 & 0.002 & & & & & \\
\hline $\operatorname{Int}_{p H}$ & 0.449 & 0.074 & 0.397 & 0.120 & 0.094 & 0.068 & 0.357 & 0.368 & 0.413 & 0.256 & 0.461 & 0.314 & 0.384 & 0.272 & & & & & \\
\hline$K_{p H V F A}$ & 0.255 & 0.040 & 0.221 & 0.071 & 0.042 & 0.030 & 0.193 & 0.219 & 0.206 & 0.139 & 0.225 & 0.165 & 0.237 & 0.147 & & & & & \\
\hline$K_{A b s A c}$ & 0.030 & 0.002 & 0.057 & 0.197 & 0.126 & 0.108 & 0.035 & 0.031 & 0.031 & 0.024 & 0.032 & 0.012 & 0.026 & 0.030 & & & & & \\
\hline$K_{A b s P r}$ & 0.009 & 0.001 & 0.014 & 0.217 & 0.398 & 0.027 & 0.009 & 0.007 & 0.010 & 0.007 & 0.010 & 0.002 & 0.008 & 0.008 & & & & & \\
\hline$K_{A b s B u}$ & 0.001 & 0.001 & 0.004 & 0.056 & 0.007 & 0.387 & 0.002 & 0.002 & 0.002 & 0.002 & 0.002 & 0.001 & 0.002 & 0.003 & & & & & \\
\hline$F_{K R u A D F}$ & 0.033 & 0.002 & 0.069 & 0.001 & 0.001 & 0.0004 & 0.067 & 0.057 & 0.063 & 0.015 & 0.030 & 0.014 & 0.024 & 0.022 & & & & & \\
\hline$F_{K R U P}$ & 0.003 & 0.113 & 0.005 & 0.002 & 0.003 & 0.001 & 0.004 & 0.001 & 0.001 & 0.003 & 0.002 & 0.152 & 0.001 & 0.140 & & & & & \\
\hline$F_{K R u S t}$ & 0.003 & 0.0005 & 0.004 & 0.002 & 0.001 & 0.001 & 0.006 & 0.002 & 0.001 & 0.199 & 0.002 & 0.001 & 0.002 & 0.002 & & & & & \\
\hline$K_{H c C s 1}$ & 0.011 & 0.001 & 0.020 & 0.001 & 0.001 & 0.001 & 0.025 & 0.019 & 0.003 & 0.004 & 0.008 & 0.004 & 0.008 & 0.006 & & & & & \\
\hline$K_{F G A m}$ & 0.0004 & 0.001 & 0.0004 & 0.0005 & 0.001 & 0.001 & 0.001 & 0.0005 & 0.0005 & 0.001 & 0.001 & 0.002 & 0.002 & 0.001 & & & & & \\
\hline$K_{F a t F G}$ & 0.0003 & 0.003 & 0.0003 & 0.001 & 0.001 & 0.001 & 0.0004 & 0.001 & 0.001 & 0.002 & 0.003 & 0.005 & 0.003 & 0.002 & & & & & \\
\hline$K_{F a t H b}$ & 0.0004 & 0.001 & 0.0004 & 0.001 & 0.0005 & 0.0005 & 0.0004 & 0.001 & 0.0002 & 0.001 & 0.0003 & 0.001 & 0.001 & 0.001 & & & & & \\
\hline$K_{F a t P i}$ & 0.0002 & 0.001 & 0.0003 & 0.001 & 0.0004 & 0.0004 & 0.001 & 0.001 & 0.0004 & 0.001 & 0.0004 & 0.001 & 0.001 & 0.001 & & & & & \\
\hline \multicolumn{20}{|l|}{ Postruminal } \\
\hline$K_{\text {Starch.LGut }}$ & & & & & & & & & & & & & & & 0.754 & 0.041 & 0.021 & 0.017 & 0.025 \\
\hline$K_{\text {Fiber,LGut }}$ & & & & & & & & & & & & & & & 0.003 & 0.286 & 0.350 & 0.006 & 0.008 \\
\hline$K_{\text {Lipid,LGut }}$ & & & & & & & & & & & & & & & 0.003 & 0.018 & 0.016 & 0.004 & 0.414 \\
\hline$K_{\text {Protein }, \text { LGut }}$ & & & & & & & & & & & & & & & 0.001 & 0.016 & 0.019 & 0.630 & 0.007 \\
\hline
\end{tabular}

¿ $\quad{ }^{1}$ Parameter bounds were set to 70 and $130 \%$ of the final parameter estimates (Table 6), except for $K_{F a t H b}$ and $K_{F a t P i}$, which were set to 0 and 0.01 . Data are expressed as a fraction of the total variance.

D. ${ }^{2}$ Definitions for each of the model parameters are given in Table 6.

글 ${ }^{3} \mathrm{Am}=$ ammonia; $\mathrm{Ac}=$ proportion of VFA as acetate; $\mathrm{Pr}=$ proportion of VFA as propionate; $\mathrm{Bu}=$ proportion of VFA as butyrate; $\mathrm{DMP}=\mathrm{DM}$ passage; NDFP $=\mathrm{NDF}$ passage; $\mathrm{ADFP}=\mathrm{ADF}$ passage; HaP $=$ start passage; LipidP $=$ lipid passage; NitP $=$ nitrogen passage; MiNP $=$ microbial nitrogen passage; $\mathrm{NANMNP}=$ nonammonia, nonmicrobial nitrogen passage. 
The global sensitivity analyses did not demonstrate the same level of interdependence of these model parameters (Table 5).

Derived parameters for the ruminal $\mathrm{pH}$ equation within the model also deviated considerably from the original parameters, but corresponded closely with the above direct regression results, with an intercept of 6.53 and a VFA coefficient of $-3.94 \mathrm{~mol}^{-1}$. Based on this equation, a $10-\mathrm{m} M$ increase in VFA concentrations could be expected to reduce the ruminal $\mathrm{pH}$ by $0.04 \mathrm{pH}$ units. These changes reduced the root MSPE from 7 to $4 \%$ and removed all of the mean bias. The lack of slope bias suggests that the equation form and derived parameters are consistent with observations, and that the minimal bias in VFA predictions did not significantly influence the outcome.

Altered $\mathrm{pH}$ predictions contributed to changes in several additional parameters, as the flow of all nutrients, including microbial protein from the rumen, and concentrations of VFA were sensitive to alterations in the $\mathrm{pH}$ prediction parameters (Table 5). The very large reduction in the parameter value for $F_{K R u A D F}$ was due to alleviation of the predicted $\mathrm{pH}$ suppression of fiber degradation (Argyle and Baldwin, 1988). Restoration of $\mathrm{pH}$ predictions to more normal ranges removed the predicted inhibition, allowing adoption of a more reasonable value for $F_{K R U A D F}$ while maintaining appropriate predictions of fiber passage from the rumen. Using the derived value for $F_{K R u A D F}$ and the mean observed nutrient inputs to calculate $K_{\text {Deg,Cellulose }}$ (Equation 4) yielded a value of 6.63 , which is only $10 \%$ greater than the original estimate of 6.0 by Baldwin (1995). The scalar relating hemicellulose to cellulose degradation increased approximately 2 fold to a value of 0.96 , which indicates that the rate of degradation of cellulose and hemicelluloses are almost equal, again more consistent with the original settings by Baldwin (1995). Small changes in rate parameters for protein and starch degradation reflect the lesser sensitivity of those flows (Table 5) to the indirect effects of $\mathrm{pH}$ on microbial-driven degradation of those nutrients in the model (Baldwin, 1995).

Overall error in microbial $\mathrm{N}$ predictions was reduced modestly from 30 to $27 \%$, and the mean bias was removed, with essentially no slope bias. The reduction in overall error resulted primarily from improved predictions of $\mathrm{pH}$, with a minor contribution from improved predictions of fiber fermentability (Table 5). Although refined estimates of the effects of ammonia and fat contributed to improved model performance, sensitivity to those parameters was exceedingly small compared with the large $\mathrm{pH}$ effects. Improved microbial flow predictions contributed to a reduction in errors for total $\mathrm{N}$ flow from 23 to $19 \%$, due largely to a reduction in mean bias.

Nonammonia, nonmicrobial $\mathrm{N}$ prediction error increased very slightly from 33 to $35 \%$ with essentially no mean bias and possibly a small amount of slope bias. Regression of residuals for NANMN on $K_{\text {Deq,RUP }}$ (Equation 4) indicates that the variation in that parameter, which is driven by specified feed inputs, is not the cause of the variation in NANMN flow predictions (Figure 2). A slight trend exists for an underprediction of NANMN flow when calculated rate constants are high (low-RUP diets) and the reverse with low settings, suggesting that minor gains may be possible if Equation 4 were reformulated to create greater change in the resulting rate constant as dietary RUP estimates change. The relatively large additive term $F_{K D e g, R U P}$ effectively dampens the proportional response, resulting in a mean rate constant of 3.57 and a range of 85 to $123 \%$ of that value, whereas the negative logarithm of RUP divided by insoluble protein ranged from 65 to $133 \%$ of the mean value.

Very little reduction in prediction errors was observed for ruminal VFA concentrations, with an overall prediction error of $21 \%$. The reduction was associated with removal of mean bias, with prior predictions averaging $97 \mathrm{~m} M$ versus the observed $106 \mathrm{~m} M$. Some of this variance is likely associated with heterogeneity in the observed data caused by variation in ruminal sampling technique. However, predictions of VFA production, and the simple mass action representation for absorption of the VFA likely contribute to the problem. The much greater sensitivity of concentrations to factors affecting production (i.e., $\mathrm{pH}$, as compared with those regulating absorption; Table 5) suggest that the problem is primarily associated with predictions of production. Ghimire et al. (2012) observed large errors associated with predictions of VFA production rates. In addition to reported $\mathrm{pH}$ effects on transport (Dijkstra et al., 1993), Storm et al. (2011, 2012) found that ruminal blood flow also regulates VFA uptake. Neither of these effects is captured in the current absorption prediction equations. Although the observed prediction errors are worrisome from the point of predicting animal production responses to dietary nutrients, VFA exert no direct effect on any ruminal elements other than $\mathrm{pH}$; thus, the sensitivity of nutrient outflow from the rumen to VFA absorption parameters simply reflects the effects of VFA on $\mathrm{pH}$ (Table 5).

Prediction errors for ammonia concentrations actually increased substantially due primarily to an increase in mean bias. Predicted ammonia concentrations are most sensitive to the settings for the rate constant for absorption, ruminal $\mathrm{pH}$, and the rate of protein degra- 
Table 6. Model parameters derived when the model was fitted to the data summarized in Table 2

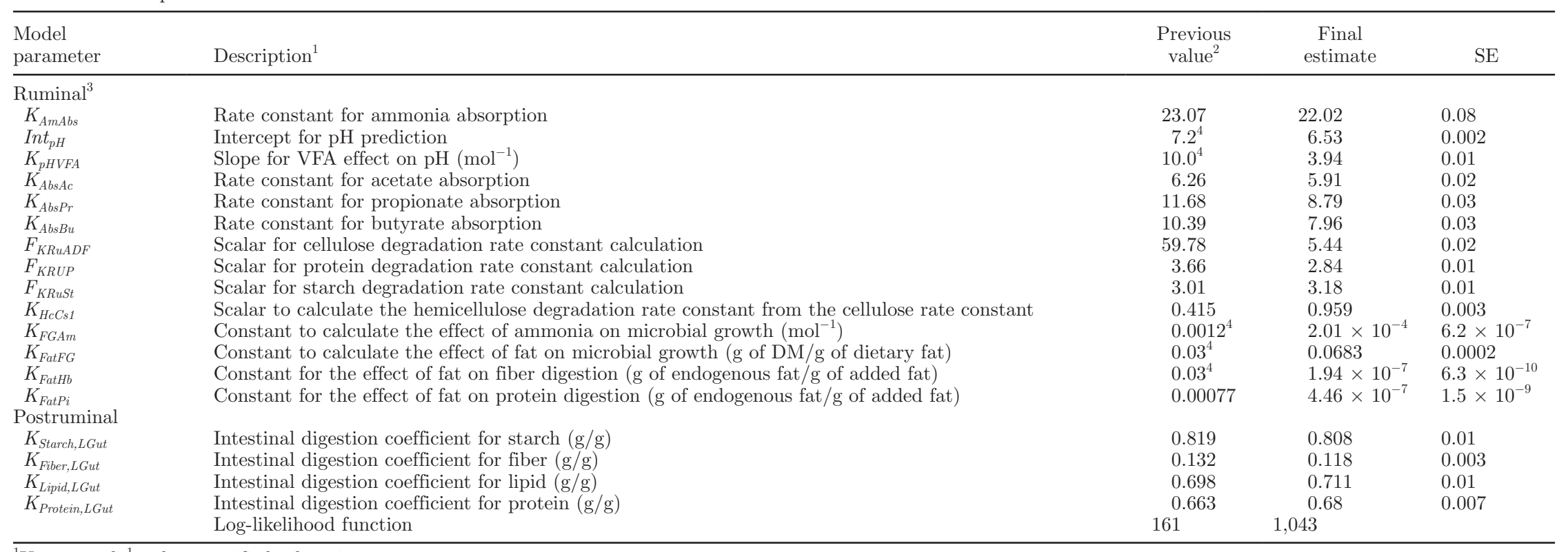

d-1 unless specified otherwise.

${ }^{2}$ From Hanigan et al. (2009).

Q ${ }^{3}$ Ruminal parameters were derived as a set and fixed for subsequent derivation of postruminal parameters.

글 ${ }^{4}$ From the original model description by Baldwin (1995). 
Table 7. Correlations among ruminal parameters ${ }^{1}$

\begin{tabular}{|c|c|c|c|c|c|c|c|c|c|c|c|c|c|c|}
\hline Item & $K_{A m A b s}$ & $\operatorname{Int}_{p H}$ & $F_{K R u A D F}$ & $F_{K R U P}$ & $F_{K R u S t}$ & $K_{H c C s 1}$ & $K_{F a t F G}$ & $K_{p H V F A}$ & $K_{F a t H b}$ & $K_{F a t P i}$ & $K_{A b s A c}$ & $K_{A b s P r}$ & $K_{A b s B u}$ & $K_{F G A m}$ \\
\hline$K_{A m A b s}$ & 1.000 & & & & & & & & & & & & & \\
\hline $\operatorname{Int}_{p H}$ & -0.145 & 1.000 & & & & & & & & & & & & \\
\hline$F_{K R u A D F}$ & -0.037 & -0.227 & 1.000 & & & & & & & & & & & \\
\hline$F_{K R u S t}$ & -0.072 & -0.116 & -0.144 & -0.070 & 1.000 & & & & & & & & & \\
\hline$K_{H c C s 1}$ & -0.155 & -0.057 & -0.147 & -0.092 & -0.190 & 1.000 & & & & & & & & \\
\hline$K_{\text {FatFG }}$ & -0.140 & -0.119 & -0.093 & 0.078 & -0.193 & 0.085 & 1.000 & & & & & & & \\
\hline$K_{A b s A c}$ & -0.129 & -0.165 & -0.121 & -0.068 & -0.002 & -0.102 & -0.079 & -0.204 & -0.101 & -0.127 & 1.000 & & & \\
\hline$K_{A b s P r}$ & -0.076 & -0.070 & -0.015 & -0.168 & -0.023 & -0.189 & -0.215 & 0.046 & -0.124 & -0.121 & -0.143 & 1.000 & & \\
\hline$K_{A b s B u}$ & -0.102 & -0.096 & -0.021 & -0.178 & -0.136 & -0.049 & -0.135 & -0.075 & -0.052 & -0.051 & -0.014 & -0.101 & 1.000 & \\
\hline$K_{F G A m}$ & -0.084 & -0.099 & -0.041 & -0.119 & -0.105 & -0.061 & -0.106 & -0.152 & -0.132 & -0.132 & -0.041 & -0.094 & -0.178 & 1.000 \\
\hline
\end{tabular}

${ }^{1}$ Definitions of the ruminal parameters are given in Table 6 .

dation in the rumen (Table 5). Given that all of those parameters were optimized, the results indicate that the prediction problems are not related to substrate degradation or ruminal $\mathrm{pH}$ effects on microbial growth. This problem is discussed further in the following section.

Some of the imprecision in predicting ruminal concentrations of hydrogen ions, VFA, and ammonia could be due to potential problems with predictions of ruminal volume and liquid passage. The former was considered as a constant proportion of ruminal DM contents and the latter as a constant fractional proportion of the ruminal pool (Baldwin, 1995). Deviations from these assumptions would introduce bias in concentration predictions, which could contribute to the observed prediction errors. Argyle and Baldwin (1988) provided predictions of ruminal volume and liquid passage based on a mechanistic representation; however, those equations have not been thoroughly tested. Additionally, because liquid volume is predicted from osmotic po-

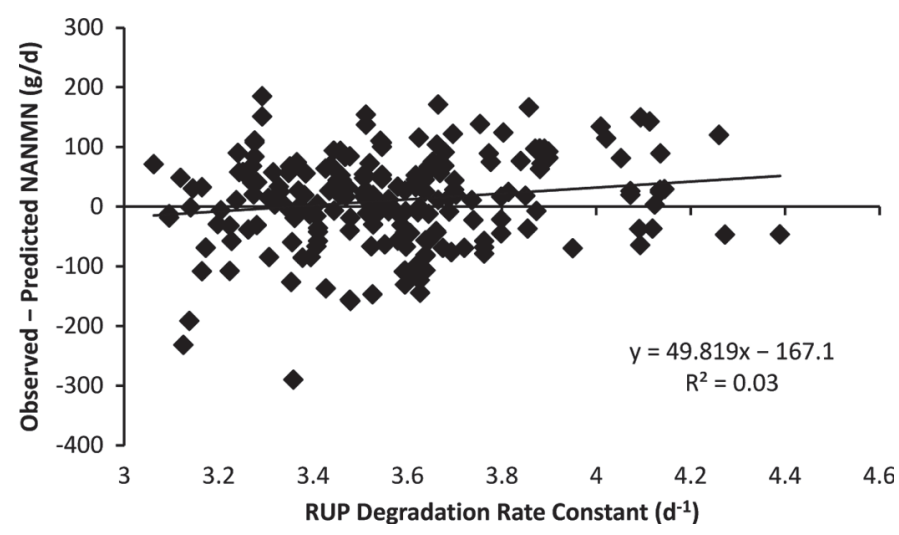

Figure 2. Residual errors for predictions of nonammonia, nonmicrobial nitrogen (NANMN) versus the calculated rate constant for degradation of insoluble protein in the rumen (Equation 4). tential in that submodel, soluble ash is a critical model input that is completely missing from the current data and, thus, those equations were not used to predict ruminal volume for this work. In addition to soluble ash inputs, it is critical to predict nutrient degradation and solubilization to predict osmotic potential and ruminal fluid balance. Thus, the problem is circular, requiring that both fluid balance and nutrient degradation and fermentation parameter sets be derived simultaneously to achieve the ideal solution. We are currently working to assess the fluid volume and passage rate equations and will revisit parameterization of absorption coefficients in conjunction with that work.

The new parameter set resulted in substantial reductions in prediction errors for postruminal protein digestion and smaller reductions in prediction errors for postruminal fiber digestion. The proportion of MSPE associated with slope bias increased slightly for protein digestion but decreased substantially for fiber digestion. Although the proportion of error associated with slope bias for postruminal protein digestion more than doubled, the sums of squares associated with slope bias were essentially constant, indicating that reparameterization did not alter the problem; it simply reduced the overall error, resulting in slope bias assuming a greater percentage of the error.

\section{Nutrient Interactions}

Several nutrient interactions on digestion are encoded in the model (i.e., inhibition of ruminal fiber and protein digestion by fat). If these interactions are inappropriately represented or parameterized or if additional interactions should be represented but have not been included in the model, the model would exhibit bias where those nutrients were substantially altered from the mean. Inappropriate representations or miss- 
ing representations would be apparent in the residual errors when they are regressed on the interacting variables using a meta-approach to restrict inference space to within an experiment. For example, if fat does not significantly inhibit ruminal protein degradation (which appears to be the case) when the model represents such an interaction, one would observe a correlation between dietary fat content and residual errors for protein passage from the rumen. The same would be the case if some other nutrient affected protein degradation but that interaction was not encoded in the model. Finally, fat may suppress degradation or digestion of another nutrient, but if the effect is improperly represented, residual errors will be correlated with dietary fat, suggesting that additional model development is needed. When regressing residuals on inputs or other model variables, positive correlations indicate that the model underpredicted responses to the independent variable and negative correlations indicate overprediction of response as compared with observed responses.

Initial model evaluations indicated that model predictions of microbial growth responses to ammonia and dietary fat, and ruminal protein and fiber degradation responses to dietary fat were inappropriate. These interactions are controlled by the variables $K_{F G A m}$ (the constant to calculate the effect of ammonia on microbial growth; $\mathrm{mol}^{-1}$ ), $K_{F a t F G}, K_{F a t H b}$ and $K_{F a t P i}$, respectively, and thus they were added to the parameters being estimated, which resulted in a reduction in the correlations (Table 8) and a reduction in model prediction errors.

The model represents microbial growth as a function of fermentable substrate availability and efficiency of conversion of ATP derived from the fermentable substrate to microbial mass $\left(\mathrm{Y}_{\mathrm{ATP}}\right)$. Ruminal ammonia affects $\mathrm{Y}_{\text {ATP }}$ in a saturable manner and long-chain FA in a linear manner. Baldwin (1995) used a MichaelisMenten equation with a maximal effect $\left(\mathrm{V}_{\max }\right)$ of 1 and an ammonia affinity constant $\left(K_{F G A m}\right)$ of $1.2 \mathrm{mM}$ to encode the ammonia response. After fitting to the data herein, $K_{F G A m}$ solved to a value of $0.2 \mathrm{~m} M$ as compared with the average ruminal ammonia concentrations of $8.8 \mathrm{mM}$ (Table 2). This results in microbial growth being essentially saturated with ammonia at average concentrations. Reducing ruminal ammonia from 8.8 to $1 \mathrm{~m} M$, the lowest value in the observed range, would result in only a $15 \%$ predicted reduction in growth rate and increasing it to $23 \mathrm{mM}$, the highest value in the observed range, would only stimulate growth by $2 \%$, given a $K_{F G A m}$ value of $0.2 \mathrm{~m} M$. Satter and Slyter (1974) observed increases in microbial yields that were maximized at ruminal ammonia concentrations of 3.5 $\mathrm{m} M$, which would be predicted to yield $95 \%$ of maximal growth at a $K_{F G A m}$ of $0.2 \mathrm{mM}$. However, Kang-Meznarich and Broderick (1980) and Reynal and Broderick
(2005) reported that microbial protein synthesis was not maximized until ruminal $\mathrm{NH}_{3}-\mathrm{N}$ concentrations exceeded 6.0 and $8.4 \mathrm{~m} M$, respectively, which correspond to 96.8 and $97.7 \%$ of maximal growth with $K_{F G A m}$ set to $0.2 \mathrm{mM}$. Although microbial $\mathrm{N}$ flow predictions were improved using the new estimate, residual errors were still positively correlated with ruminal ammonia predictions, indicating that the model was underresponsive. Therefore, the true value for the half-maximal response may be somewhat greater than the current estimate, but almost certainly less than the value of $1.2 \mathrm{mM}$. However, the large slope bias in predicted ruminal ammonia concentrations limits the confidence one can have in determining the actual minimal ruminal ammonia concentrations and underscores the need to improve those predictions (Arriola Apelo et al., 2011).

The effect of long-chain FA derived from fats and oils on microbial growth is thought to be due to energy sparing resulting from alleviating the need to synthesize FA de novo in support of growth (Doreau and Ferlay, 1995) or inhibition of bacterial predation (Palmquist and Jenkins, 1980; Pantoja et al., 1995). The energysparing effect is consistent with observations that $8 \%$ of dietary lipid intake is converted to microbial lipid (Jenkins, 1993). The model assumes that this increase in microbial growth efficiency is restricted to fats and oils added to the diet; however, the observed correlations of microbial $\mathrm{N}$ passage errors with endogenous dietary lipid intake supports the use of other types of plant lipids to offset microbial FA synthesis. The linear effect of long-chain FA derived from oilseeds, grease, tallow, and calcium salts of FA, among other sources, on microbial growth efficiency is scaled with the parameter $K_{F a t F G}$, where a value of 0 results in no stimulatory effect. No gains in efficiency were assumed from endogenous plant lipids present in the diet (Baldwin, 1995). After fitting to the data, $K_{F a t F G}$ solved for a value of 0.068 , which is slightly more than double the value of 0.03 used by Baldwin (1995). Assuming that endogenous plant lipids average approximately $3 \%$ of dietary DM yields a $1 \%$ increase in microbial efficiency for every 1 percentage unit increase in dietary fat on a DM basis when $K_{\text {FatFG }}$ is set to 0.03 , and a $2.27 \%$ increase in efficiency when $K_{F a t F G}$ is set to 0.068 .

Baldwin (1995) also included factors to inhibit fiber and protein digestion when oils and fats were added to the diet. These effects were captured as linear functions of the ratio of added fat over endogenous plant lipid, again multiplied by scalars $\left(K_{F a t H b}\right.$ and $K_{F a t P i}$, respectively) to alter sensitivity. Although reports exist of the inhibitory effects of fat on fiber degradation in the rumen (Palmquist and Jenkins, 1980; Pantoja et al., 1995), it appears these effects are restricted to high levels of unsaturated fat feeding (Doreau et al., 1991; 
Table 8. Regression analyses of residual errors from final model predictions ${ }^{1}$

\begin{tabular}{|c|c|c|c|c|c|c|c|c|c|c|c|c|c|}
\hline \multirow[b]{3}{*}{$\begin{array}{l}\text { Regression } \\
\text { variable }^{2}\end{array}$} & \multicolumn{13}{|c|}{ Predicted variable } \\
\hline & \multicolumn{6}{|c|}{ Ruminal metabolism } & \multicolumn{7}{|c|}{ Ruminal outflow (kg/d) } \\
\hline & $\mathrm{pH}$ & $\begin{array}{c}\mathrm{Amm} \\
(\mathrm{mol} / \mathrm{L})\end{array}$ & $\begin{array}{c}\text { VFA } \\
(\mathrm{mol} / \mathrm{L})\end{array}$ & $\begin{array}{c}\text { Acet } \\
(\% \text { of VFA) }\end{array}$ & $\begin{array}{c}\text { Prop } \\
(\% \text { of VFA) }\end{array}$ & $\begin{array}{c}\text { Buty } \\
(\% \text { of VFA) }\end{array}$ & Starch & $\mathrm{NDF}$ & $\mathrm{ADF}$ & Lipid & $\mathrm{N}$ & $\mathrm{MiN}$ & NANMN \\
\hline DMI & & & 0.003 & -0.94 & 0.65 & & -0.15 & -0.16 & -0.19 & & 0.020 & & \\
\hline Nutrient intake & & & & & & & & & & & & & \\
\hline $\begin{array}{l}\text { CP } \\
\text { Soluble CP }\end{array}$ & 0.21 & -0.006 & & $\begin{array}{l}7.28 \\
4.76\end{array}$ & -3.19 & & & 0.01 & $\begin{array}{r}0.44 \\
-0.66\end{array}$ & & -0.051 & -0.055 & 0.063 \\
\hline Urea & & -0.022 & & & & & & 2.18 & -0.51 & & & -0.262 & 0.209 \\
\hline RUP & -0.24 & 0.006 & & -3.08 & 2.76 & & & & & & -0.091 & 0.036 & -0.092 \\
\hline Starch & -0.04 & 0.002 & & & & 0.56 & & & & & & & \\
\hline Soluble starch & & -0.006 & & & & -2.76 & 1.24 & & & & & & \\
\hline $\mathrm{NDF}$ & -0.06 & & & & & & & & 0.30 & 0.57 & -0.038 & & \\
\hline $\mathrm{ADF}$ & & & & -1.99 & & & & & -0.71 & -0.79 & & -0.014 & \\
\hline $\begin{array}{l}\text { Lignin } \\
\text { Added fat }\end{array}$ & & 0.007 & -0.024 & & & & & -1.57 & & & -0.032 & & -0.065 \\
\hline Endogenous lipid ${ }^{3}$ & & & & & & & & & 7.29 & & -0.032 & 0.264 & \\
\hline Ash & -0.19 & 0.005 & & -4.18 & 3.83 & & 2.74 & & & -0.24 & & & \\
\hline BW & & & & & -0.03 & & & & & & 0.001 & & 0.001 \\
\hline Ruminal pH & & & 0.352 & & 33.4 & & & & & & 0.817 & 0.489 & -0.309 \\
\hline Ruminal ammonia & -14.0 & & & -539 & 258 & 16.14 & & -94.8 & & & & 11.5 & -10.50 \\
\hline
\end{tabular}

${ }^{1}$ Residuals for ruminal pH, ammonia (Amm), VFA, acetate (Acet), propionate (Prop), and butyrate (Buty), and ruminal outflow of starch, NDF, ADF, lipid, nitrogen, microbial nitrogen (MiN), and nonammonia, nonmicrobial nitrogen (NANMN) were regressed on DMI, nutrient intakes, BW, predicted ruminal pH, and predicted ruminal ammonia concentrations. Experiment was included as a random effect in the regression model. All variables remaining in the model were significant $(P<0.10)$. Positive values denote underpredictions and negative values denote overpredictions.

${ }^{2}$ Independent variables have units of kilograms per day except for BW $(\mathrm{kg})$, ruminal $\mathrm{pH}$, and ammonia $(\mathrm{mol} / \mathrm{L})$.

${ }^{3}$ Lipids naturally present in forage and grain. 
Klusmeyer et al., 1991a; Ohajuruka et al., 1991; Chan et al., 1997). Within the current data set with reported total dietary fat ranging up to $20 \%$ of $\mathrm{DM}$, there was essentially no support for fat inhibition of protein digestion (Table 6). Baldwin (1995) noted that fat effects on fiber and protein degradation were poorly supported and, thus, tentative additions. Because $K_{F a t P i}$ and $K_{F a t H b}$ both solved for values that were essentially 0 , any effects are very small. However, the lack of an effect of fat on fiber digestion may also reflect the fact that few of the studies examined the effects of unsaturated and unprotected fat sources. Because the model is not configured to represent differential effects of saturated and unsaturated fat, it is not able to capture any potential effects of unsaturated FA and, thus, may fail when challenged with data derived from diets supplemented with oils.

Although the above changes improved predictions of microbial yield, residual errors were still correlated with $\mathrm{N}, \mathrm{ADF}$, and lipid intakes as well as predictions of ruminal $\mathrm{pH}$ and ammonia (Table 8), indicating that the model does not adequately represent those interactions, or, in the case of $\mathrm{pH}$ and ammonia, bias in model predictions of those variables may be contributing to error in microbial yield predictions. Residual errors for ruminal $\mathrm{pH}$ were correlated positively with $\mathrm{CP}$ intake and negatively correlated with RUP, starch, NDF, ash intake, and ruminal ammonia concentration (Table 8). Correlations with the nutrient intakes may reflect inappropriate predictions of the relationships between available substrate supply and rates and patterns of ruminal fermentation, given the moderate errors in nutrient-degradation predictions. Although observed ammonia concentrations were not found to correlate with observed ruminal $\mathrm{pH}$, ruminal ammonia concentrations were found to be correlated with residual errors for $\mathrm{pH}$ predictions suggesting that addition of ammonia to the $\mathrm{pH}$ prediction equation may have some merit. But although such an addition may improve model performance, it does not appear to be supported by observational data and may simply reflect model problems in predicting ammonia.

Ash, starch, protein, and NDF all contribute to osmotic balance in the rumen, which plays a role in determining the concentration of VFA and $\mathrm{H}$ in the rumen (Argyle and Baldwin, 1988). As noted above, because additional assumptions would have been required to define ash inputs to the water balance submodel, simulations were conducted with that submodel turned off and water volume predicted as a constant proportion of ruminal DM. Therefore, it cannot be determined whether lack of consideration of osmotic pressure and water balance across the rumen wall is contributing to $\mathrm{pH}$ prediction bias.
Ruminal ammonia residual errors were negatively correlated with intakes of CP, urea, and soluble starch intakes, and positively correlated with RUP, starch, lignin, and ash intakes. The negative correlations with CP, urea, and soluble starch intakes and positive correlation with RUP intake suggest that ammonia absorption and urea entry into the rumen may not be properly represented or parameterized. The model considers urea entry into the rumen by saliva, urea transport across the rumen wall, and inhibition of urea entry by ruminal ammonia, all of which are supported by experimental observations (Kennedy and Milligan, 1980; Huntington, 1989). Collectively, the residual slopes suggest that cycling of $\mathrm{N}$ from blood urea into the gut and back to urea via ammonia is too slow, allowing ammonia concentrations to respond too much to changes in $\mathrm{N}$ supply and stimulation of ammonia use by ruminal microbes in response to increased fermentable substrate (Kennedy and Milligan, 1980; Clark et al., 1992; Lobley et al., 2000). Increased rates of cycling would allow ruminal ammonia concentrations to be buffered from the blood urea pool, thereby dampening responses. Because residual analyses included experiment effects, it is less likely the observed correlations are due to diversity in sampling location or time after feeding (Storm et al., 2011) across experiments and, thus, must represent a fundamental deficiency in the model. Correcting this problem would require observations of urea recycling to the rumen and ammonia absorption.

Residual errors for VFA were positively correlated with DMI and ruminal $\mathrm{pH}$ and negatively correlated with lignin intake (Table 8). Dry matter intake was also negatively correlated with residuals for starch, $\mathrm{NDF}$, and ADF flow from the rumen. The latter suggests that predicted passage rates of these nutrients increases too much as DMI increases, which is consistent with underpredictions of VFA concentrations (i.e., substrate is predicted to pass out of the rumen instead of being fermented to VFA). The positive correlation of VFA concentrations with ruminal $\mathrm{pH}$ suggests that VFA absorption should be stimulated by low ruminal $\mathrm{pH}$, which has been observed experimentally (Stevens and Stettler, 1966), but is not encoded in the model (Baldwin, 1995). The negative correlation with lignin may reflect the lack of consideration of the inhibitory effect of lignin on cellulose and hemicellulose digestion. If lignin renders some portion of the normally digestible fiber indigestible (Van Soest, 1982), failure to consider that effect would result in too much fiber degradation and VFA production at high lignin intakes.

The correlations between the molar proportion of acetate and intake of $\mathrm{DM}$ and several nutrients $(\mathrm{CP}$, RUP, and ash) and ruminal concentrations of ammonia, and correlations of the opposite sign for the same 
independent variable effects on molar proportion of propionate strongly suggest that the submodel to determine VFA stoichiometric coefficients is inadequate, which is supported by a direct assessment of the VFA model using observed de novo synthesis data (Ghimire et al., 2012). Individual VFA are predicted as a function of total VFA production using a set of fixed molar proportions unique to each major nutrient class (soluble carbohydrate, protein, and fiber; Murphy et al., 1982). The opposing signs on the correlations are clear indicators that these stoichiometric coefficients or the entire approach to deriving fractional production of each VFA is inappropriate (Bannink et al., 1997). Given the importance of acetate as an energy source, propionate as a glucose source and a stimulator of insulin secretion, and the effect of the ratio of the two on methane production (Czerkawski, 1969; Whitelaw et al., 1984), correcting this deficiency in the model is extremely important. However, such a correction cannot be achieved with certainty using only VFA concentration data, as VFA absorption is not simply a function of ruminal VFA concentrations and pH (Storm et al., 2011). Thus, concentrations are not always proportional to production as has previously been assumed (Murphy et al., 1982; Bannink et al., 1997). Addressing the VFA production problem is supported by the work herein, as predictions of fermentable nutrient supply are required as inputs to the VFA submodel.

Ruminal concentrations of butyrate are generally less variable due possibly to reduced variation in butyrate production and the importance of butyrate in regulating ruminal blood flow and VFA absorption (Storm et al., 2011). Because butyrate concentrations drive the rate of uptake of butyrate from the rumen, concentration changes will be dampened with respect to production rates, thereby minimizing variation that could correlate with independent variables. However, the regulation of blood flow by butyrate would also have profound effects on acetate and propionate absorption, which may explain a portion of the prediction errors for acetate and propionate concentrations.

Residual errors for starch, NDF, and ADF passage to the small intestine were all negatively correlated with DMI, indicating that the model overpredicted outflow of these nutrients at high intake. Because the degradation rates were fitted to the observed intakes and flows, these correlations may suggest that particle passage rate is being predicted inappropriately. The version of the model used defines small particle passage rate as a mass action function of the small particle pool size. Earlier versions of the model (Baldwin, 1995) predicted small particle passage from BW and DMI using a regression equation derived from literature data (Evans, 1981; Robinson et al., 1985). Because residuals for these 3 nutrients were correlated with DMI in the current work, reinstating the prior passage equation may improve residual bias. The lack of correlation of errors with BW may simply reflect an inadequate range in $\mathrm{BW}$ within this data set.

\section{CONCLUSIONS}

Although a meta-analysis should provide superior response parameter estimates, it is unclear how those parameters can be used in a global model such as Molly in the absence of knowledge of the cause of differences among experiments. A meta-approach was used, however, to guide model enhancements to capture some of the underlying reasons for experiment effects, thus explicitly representing that knowledge rather than treating it as a random event. Using such an approach in refitting digestive parameters to a large set of lactating cow observations resulted in significant improvements for predictions of some variables and more modest improvements for others. Key improvements were removal of mean bias in predictions of ruminal $\mathrm{pH}, \mathrm{NDF}$ and microbial $\mathrm{N}$ outflow from the rumen, and postruminal NDF digestion, and reductions in slope bias for predictions of the proportions of all $3 \mathrm{VFA}$ and postruminal digestion of fiber. Key findings supporting the improved performance were that $\mathrm{pH}$ responses to ruminal VFA concentrations are one-third of the previously estimated slope, the half-maximal microbial growth response to ruminal ammonia was one-sixth of the previous estimate, the efficiency of microbial growth in response to added dietary fat appears to be twice the previous estimate, and added fat had no observable negative effect on protein and fiber degradation. Results indicated that additional improvements in model performance could be achieved through better representations of particle passage from the rumen, VFA production, the effects of ruminal $\mathrm{pH}$ on microbial growth efficiency, cycling of urea and ammonia across the rumen wall, and postruminal fiber digestion.

\section{ACKNOWLEDGMENTS}

Funding support was provided by the Virginia State Dairymen's Association (Bridgewater, VA) and the College of Agriculture and Life Sciences of Virginia Tech. (Blacksburg). Salary support for M. D. Hanigan was provided by the New Zealand Dairy Farmers through DairyNZ Ltd. (Hamilton, New Zealand).

\section{REFERENCES}

AFRC (Agriculture and Food Research Council). 1993. Energy and Protein Requirements of Ruminants. CAB International, Wallingford, Oxon, UK. 
AFRC (Agriculture and Food Research Council). 1998. Responses in the yield of milk constituents to the intake of nutrients by dairy cows. AFRC Technical Committee on Responses to Nutrients, Report No. 11. CAB International, Wallingford, Oxon, UK.

Aldrich, J. M., L. D. Muller, G. A. Varga, and L. C. Griel Jr. 1993. Nonstructural carbohydrate and protein effects on rumen fermentation, nutrient flow, and performance of dairy cows. J. Dairy Sci. 76:1091-1105.

Argyle, J. L., and R. L. Baldwin. 1988. Modeling of rumen water kinetics and effects of rumen $\mathrm{pH}$ changes. J. Dairy Sci. 71:1178-1188.

Armentano, L. E., T. A. Herrington, C. E. Polan, A. J. Moe, J. H. Herbein, and P. Umstadt. 1986. Ruminal degradation of dried brewers grains, wet brewers grains, and soybean meal. J. Dairy Sci. 69:2124-2133.

Arriola Apelo, S. I., E. C. Titgemeyer, and M. D. Hanigan. 2011. Improved representation of urea cycling in Molly. Can. J. Anim. Sci. 91:725.

Baldwin, R. L. 1995. Modeling Ruminant Digestion and Metabolism. Chapman and Hall, London, UK.

Baldwin, R. L., J. France, D. E. Beever, M. Gill, and J. H. M. Thornley. 1987a. Metabolism of the lactating cow. III. Properties of mechanistic models suitable for evaluation of energetic relationships and factors involved in the partition of nutrients. J. Dairy Res. 54:133-145.

Baldwin, R. L., J. France, and M. Gill. 1987b. Metabolism of the lactating cow. I. Animal elements of a mechanistic model. J. Dairy Res. 54:77-105.

Baldwin, R. L., J. H. M. Thornley, and D. E. Beever. 1987c. Metabolism of the lactating cow. II. Digestive elements of a mechanistic model. J. Dairy Res. 54:107-131.

Bannink, A., H. De Visser, A. Klop, J. Dijkstra, and J. France. 1997. Causes of inaccurate prediction of volatile fatty acids by simulation models of rumen function in lactating cows. J. Theor. Biol. 189:353-366

Batajoo, K. K., and R. D. Shaver. 1994. Impact of nonfiber carbohydrate on intake, digestion, and milk production by dairy cows. J. Dairy Sci. 77:1580-1588.

Batajoo, K. K., and R. D. Shaver. 1998. In situ dry matter, crude protein, and starch degradabilities of selected grains and by-product feeds. Anim. Feed Sci. Technol. 71:165-176.

Beukes, P. C., P. Gregorini, and A. J. Romera. 2011. Estimating greenhouse gas emissions from New Zealand dairy systems using a mechanistic whole farm model and inventory methodology. Anim. Feed Sci. Technol. 166-67:708-720.

Beukes, P. C., P. Gregorini, A. J. Romera, G. Levy, and G. C. Waghorn. 2010. Improving production efficiency as a strategy to mitigate greenhouse gas emissions on pastoral dairy farms in New Zealand. Agric. Ecosyst. Environ. 136:358-365.

Bibby, J., and H. Toutenburg. 1977. Prediction and Improved Estimation in Linear Models. Wiley, Chichester, UK.

Blauwiekel, R., S. Xu, J. H. Harrison, K. A. Loney, R. E. Riley, and M. C. Calhoun. 1997. Effect of whole cottonseed, gossypol, and ruminally protected lysine supplementation on milk yield and composition. J. Dairy Sci. 80:1358-1365.

Briggs, P. K., J. P. Hogan, and R. L. Reid. 1957. The effect of volatile fatty acids, lactic acid, and ammonia on rumen $\mathrm{pH}$ in sheep. Aust. J. Agric. Res. 8:674-690.

Calsamiglia, S., G. Caja, M. D. Stern, and B. A. Crooker. 1995. Effects of ruminal versus duodenal dosing of fish meal on ruminal fermentation and milk composition. J. Dairy Sci. 78:1999-2007.

Cameron, M. R., T. H. Klusmeyer, G. L. Lynch, J. H. Clark, and D. R. Nelson. 1991. Effects of urea and starch on rumen fermentation, nutrient passage to the duodenum, and performance of cows. J. Dairy Sci. 74:1321-1336.

Chan, S. C., J. T. Huber, C. B. Theurer, Z. Wu, K. H. Chen, and J. M. Simas. 1997. Effects of supplemental fat and protein source on ruminal fermentation and nutrient flow to the duodenum in dairy cows. J. Dairy Sci. 80:152-159.

Christensen, R. A., M. R. Cameron, T. H. Klusmeyer, J. P. Elliott, J. H. Clark, D. R. Nelson, and Y. Yu. 1993. Influence of amount and degradability of dietary protein on nitrogen utilization by dairy cows. J. Dairy Sci. 76:3497-3513.

Clark, J. H., T. H. Klusmeyer, and M. R. Cameron. 1992. Microbial protein synthesis and flows of nitrogen fractions to the duodenum of dairy cows. J. Dairy Sci. 75:2304-2323.

Cunningham, K. D., M. J. Cecava, and T. R. Johnson. 1994. Flows of nitrogen and amino acids in dairy cows fed diets containing supplemental feather meal and blood meal. J. Dairy Sci. 77:3666-3675.

Cunningham, K. D., M. J. Cecava, T. R. Johnson, and P. A. Ludden. 1996. Influence of source and amount of dietary protein on milk yield by cows in early lactation. J. Dairy Sci. 79:620-630.

Czerkawski, J. W. 1969. Methane production in ruminants and its significance. World Rev. Nutr. Diet. 11:240-282.

Danfær, A. 1990. A Dynamic Model of Nutrient Digestion and Metabolism in Lactating Dairy Cows. National Institute of Animal Science, Hillerød, Denmark.

Dijkstra, J., H. Boer, J. Van Bruchem, M. Bruining, and S. Tamminga. 1993. Absorption of volatile fatty acids from the rumen of lactating dairy cows as influenced by volatile fatty acid concentration, $\mathrm{pH}$ and rumen liquid volume. Br. J. Nutr. 69:385-396.

Dijkstra, J., H. D. Neal, D. E. Beever, and J. France. 1992. Simulation of nutrient digestion, absorption and outflow in the rumen: Model description. J. Nutr. 122:2239-2256.

Doreau, M., and A. Ferlay. 1995. Effect of dietary lipids on nitrogen metabolism in the rumen: A review. Livest. Prod. Sci. 43:97-110.

Doreau, M., F. Legay, and D. Bauchart. 1991. Effect of source and level of supplemental fat on total and ruminal organic matter and nitrogen digestion in dairy cows. J. Dairy Sci. 74:2233-2242.

Erasmus, L. J., P. M. Botha, and H. H. Meissner. 1994. Effect of protein source on ruminal fermentation and passage of amino acids to the small intestine of lactating cows. J. Dairy Sci. 77:3655-3665.

Espindola, M. S., E. J. DePeters, J. G. Fadel, R. A. Zinn, and H. Perez-Monti. 1997. Effects on nutrient digestion of wheat processing and method of tallow addition to the diets of lactating dairy cows. J. Dairy Sci. 80:1160-1171.

Evans, E. 1981. An evaluation of the relationships between dietary parameters and rumen solid turnover rate. Can. J. Anim. Sci. 61:97-103.

Feng, P., W. H. Hoover, T. K. Miller, and R. Blauwiekel. 1993. Interactions of fiber and nonstructural carbohydrates on lactation and ruminal function. J. Dairy Sci. 76:1324-1333.

Ghimire, S., P. Gregorini, and M. D. Hanigan. 2012. Prediction of volatile fatty acid production rates by the Molly cow model. Can. J. Anim. Sci. 92:552.

Gregorini, P., P. C. Beukes, R. H. Bryant, and A. J. Romero. 2010. A brief overview and simulation of the effects of some feeding strategies on nitrogen excretion and enteric methane emission from grazing dairy cows. Pages 29-43 in Proc. 4th Australasian Dairy Science Symposium. Lincoln University, Canterbury, New Zealand.

Hadrich, J. C., C. A. Wolf, J. R. Black, and S. B. Harsh. 2008. Incorporating environmentally compliant manure nutrient disposal costs into least-cost livestock ration formulation. J. Agric. Appl. Econ. 40:287-300.

Hanigan, M. D., H. G. Bateman, J. G. Fadel, J. P. McNamara, and N. E. Smith. 2006. An ingredient-based input scheme for Molly. Pages 328-348 in Nutrient Digestion and Utilization in Farm Animals: Modelling Approaches. E. Kebreab, J. Dijkstra, A. Bannink, W. J. J. Gerrits, and J. France, ed. CAB International, Wallingford, UK.

Hanigan, M. D., C. C. Palliser, and P. Gregorini. 2009. Altering the representation of hormones and adding consideration of gestational metabolism in a metabolic cow model reduced prediction errors. J. Dairy Sci. 92:5043-5056.

Hanigan, M. D., A. G. Rius, E. S. Kolver, and C. C. Palliser. 2007. A redefinition of the representation of mammary cells and enzyme activities in a lactating dairy cow model. J. Dairy Sci. 90:38163830 .

Herrera-Saldana, R., R. Gomez-Alarcon, M. Torabi, and J. T. Huber. 1990. Influence of synchronizing protein and starch degradation in the rumen on nutrient utilization and microbial protein synthesis. J. Dairy Sci. 73:142-148. 
Horner, J. L., C. E. Coppock, J. R. Moya, J. M. Labore, and J. K. Lanham. 1988. Effects of niacin and whole cottonseed on ruminal fermentation, protein degradability, and nutrient digestibility. J. Dairy Sci. 71:1239-1247.

Huntington, G. B. 1989. Hepatic urea synthesis and site and rate of urea removal from blood of beef steers fed alfalfa hay or a high concentrate diet. Can. J. Anim. Sci. 69:215-223.

Jenkins, T. C. 1993. Lipid metabolism in the rumen. J. Dairy Sci. $76: 3851-3863$

Joy, M. T., E. J. DePeters, J. G. Fadel, and R. A. Zinn. 1997. Effects of corn processing on the site and extent of digestion in lactating cows. J. Dairy Sci. 80:2087-2097.

Kalscheur, K. F., B. B. Teter, L. S. Piperova, and R. A. Erdman 1997a. Effect of dietary forage concentration and buffer addition on duodenal flow of trans-C18:1 fatty acids and milk fat production in dairy cows. J. Dairy Sci. 80:2104-2114.

Kalscheur, K. F., B. B. Teter, L. S. Piperova, and R. A. Erdman 1997b. Effect of fat source on duodenal flow of trans-C18:1 fatty acids and milk fat production in dairy cows. J. Dairy Sci. 80:2115-2126.

Kang-Meznarich, J. H., and G. A. Broderick. 1980. Effects of incremental urea supplementation on ruminal ammonia concentration and bacterial protein formation. J. Anim. Sci. 51:422-431.

Kennedy, P. M., and L. P. Milligan. 1980. The degradation and utilization of endogenous urea in the gastrointestinal tract of ruminants: A review. Can. J. Anim. Sci. 60:205-221.

King, K. J., J. T. Huber, M. Sadik, W. G. Bergen, A. L. Grant, and V. L. King. 1990. Influence of dietary protein sources on the amino acid profiles available for digestion and metabolism in lactating cows. J. Dairy Sci. 73:3208-3216.

Klusmeyer, T. H., G. L. Lynch, J. H. Clark, and D. R. Nelson. 1991a. Effects of calcium salts of fatty acids and proportion of forage in diet on ruminal fermentation and nutrient flow to duodenum of cows. J. Dairy Sci. 74:2220-2232.

Klusmeyer, T. H., G. L. Lynch, J. H. Clark, and D. R. Nelson. 1991b. Effects of calcium salts of fatty acids and protein source on ruminal fermentation and nutrient flow to duodenum of cows. J. Dairy Sci. 74:2206-2219.

Klusmeyer, T. H., R. D. J. McCarthy, J. H. Clark, and D. R. Nelson. 1990. Effects of source and amount of protein on ruminal fermentation and passage of nutrients to the small intestine of lactating cows. J. Dairy Sci. 73:3526-3537.

Kung, L., Jr., J. T. Huber, and L. D. Satter. 1983. Influence of nonprotein nitrogen and protein of low rumen degradability on nitrogen flow and utilization in lactating dairy cows. J. Dairy Sci. 66:1863-1872.

Lobley, G. E., D. M. Bremner, and G. Zuur. 2000. Effects of diet quality on urea fates in sheep as assessed by refined, non-invasive $\left.{ }^{15} \mathrm{~N}-{ }^{15} \mathrm{~N}\right]$ urea kinetics. Br. J. Nutr. 84:459-468.

Lu, C. D., N. A. Jorgensen, and L. D. Satter. 1988. Site and extent of nutrient digestion in lactating dairy cows fed alfalfa protein concentrate or soybean meal. J. Dairy Sci. 71:697-704.

Lykos, T., and G. A. Varga. 1997. Varying degradation rates of total nonstructural carbohydrates: Effects on nutrient uptake and utilization by the mammary gland in high producing Holstein cows. J. Dairy Sci. 80:3356-3367.

Lykos, T., G. A. Varga, and D. Casper. 1997. Varying degradation rates of total nonstructural carbohydrates: Effects on ruminal fermentation, blood metabolites, and milk production and composition in high producing Holstein cows. J. Dairy Sci. 80:3341-3355.

Lynch, G. L., T. H. Klusmeyer, M. R. Cameron, J. H. Clark, and D. R. Nelson. 1991. Effects of somatotropin and duodenal infusion of amino acids on nutrient passage to duodenum and performance of dairy cows. J. Dairy Sci. 74:3117-3127.

Mabjeesh, S. J., A. Arieli, I. Bruckental, S. Zamwell, and H. Tagari. 1996. Effect of type of protein supplementation on duodenal amino acid flow and absorption in lactating dairy cows. J. Dairy Sci. 79:1792-1801

Mabjeesh, S. J., A. Arieli, I. Bruckental, S. Zamwell, and H. Tagari. 1997. Effect of ruminal degradability of crude protein and nonstructural carbohydrates on the efficiency of bacterial crude pro- tein synthesis and amino acid flow to the abomasum of dairy cows. J. Dairy Sci. 80:2939-2949.

Madsen, J., and T. Hvelplund. 1985. Protein degradation in the rumen. Comparison between in vivo, nylon bag, in vitro and buffer measurements. Acta Agric. Scand. 25(Suppl.):103-124.

Mansfield, H. R., and M. D. Stern. 1994. Effects of soybean hulls and lignosulfonate-treated soybean meal, on ruminal fermentation in lactating dairy cows. J. Dairy Sci. 77:1070-1083.

McCarthy, R. D., T. H. Klusmeyer, J. L. Vicini, J. H. Clark, and D. R. Nelson. 1989. Effects of source of protein and carbohydrate on ruminal fermentation and passage of nutrients to the small intestine of lactating cows. J. Dairy Sci. 72:2002-2016.

Merchen, N. R., and L. D. Satter. 1983. Changes in nitrogenous compounds and sites of digestion of alfalfa harvested at different moisture contents. J. Dairy Sci. 66:789-801.

Murphy, M., P. Udén, D. L. Palmquist, and H. Wiktorsson. 1987. Rumen and total diet digestibilities in lactating cows fed diets containing full-fat rapeseed. J. Dairy Sci. 70:1572-1582.

Murphy, M. R., R. L. Baldwin, and L. J. Koong. 1982. Estimation of stoichiometric parameters for rumen fermentation of roughage and concentrate diets. J. Anim. Sci. 55:411-421.

Narasimhalu, P., E. Teller, M. Vanbelle, M. Foulon, and F. Dasnoy. 1989. Apparent digestibility of nitrogen in rumen and whole tract of Friesian cattle fed direct-cut and wilted grass silages. J. Dairy Sci. 72:2055-2061.

NRC. 1978. Nutrient Requirements of Dairy Cattle. 5th ed. National Academy Press, Washington, DC.

NRC. 1984. Nutrient Requirements of Beef Cattle. 6th ed. National Academy Press, Washington, DC.

NRC. 2001. Nutrient Requirements of Dairy Cattle. 7th rev. ed. National Academy Press, Washington, DC.

O'Mara, F. P., G. K. Stakelum, P. Dillon, J. J. Murphy, and M. Rath. 1997. Rumen fermentation and nutrient flows for cows fed grass and grass supplemented with molassed beet pulp pellets. J. Dairy Sci. 80:2466-2474

Ohajuruka, O. A., Z. Wu, and D. L. Palmquist. 1991. Ruminal metabolism, fiber, and protein digestion by lactating cows fed calcium soap or animal-vegetable fat. J. Dairy Sci. 74:2601-2609.

Oliveira, J. S., J. T. Huber, J. M. Simas, C. B. Theurer, and R. S. Swingle. 1995. Effect of sorghum grain processing on site and extent of digestion of starch in lactating dairy cows. J. Dairy Sci 78:1318-1327

Overton, T. R., M. R. Cameron, J. P. Elliott, J. H. Clark, and D. R. Nelson. 1995. Ruminal fermentation and passage of nutrients to the duodenum of lactating cows fed mixtures of corn and barley. J. Dairy Sci. 78:1981-1998.

Palmquist, D. L., and T. C. Jenkins. 1980. Fat in lactation rations: Review. J. Dairy Sci. 63:1-14.

Pantoja, J., J. L. Firkins, and M. L. Eastridge. 1995. Site of digestion and milk production by cows fed fats differing in saturation, esterification, and chain length. J. Dairy Sci. 78:2247-2258

Pena, F., H. Tagari, and L. D. Satter. 1986. The effect of heat treatment of whole cottonseed on site and extent of protein digestion in dairy cows. J. Anim. Sci. 62:1423-1433.

Pires, A. V., M. L. Eastridge, J. L. Firkins, and Y. C. Lin. 1997. Effects of heat treatment and physical processing of cottonseed on nutrient digestibility and production performance by lactating cows. J. Dairy Sci. 80:1685-1694.

Poore, M. H., J. A. Moore, T. P. Eck, R. S. Swingle, and C. B. Theurer. 1993. Effect of fiber source and ruminal starch degradability on site and extent of digestion in dairy cows. J. Dairy Sci $76: 2244-2253$

Prange, R. W., M. D. Stern, N. A. Jorgensen, and L. D. Satter. 1984. Site and extent of protein digestion in lactating cows fed alfalfa silage or baled alfalfa hay. J. Dairy Sci. 67:2308-2314.

Press, W. H. 2007. Numerical recipes: The art of scientific computing. 3rd ed. Cambridge University Press, Cambridge, UK and New York, NY.

Price, S. G., L. D. Satter, and N. A. Jorgensen. 1988. Dehydrated alfalfa in dairy cow diets. J. Dairy Sci. 71:727-736. 
Putnam, D. E., C. G. Schwab, M. T. Socha, N. L. Whitehouse, N. A. Kierstead, and B. D. Garthwaite. 1997. Effect of yeast culture in the diets of early lactation dairy cows on ruminal fermentation and passage of nitrogen fractions and amino acids to the small intestine. J. Dairy Sci. 80:374-384.

Reynal, S. M., and G. A. Broderick. 2005. Effect of dietary level of rumen-degraded protein on production and nitrogen metabolism in lactating dairy cows. J. Dairy Sci. 88:4045-4064.

Robinson, P. H., M. Gill, and J. J. Kennelly. 1997. Influence of time and feeding a protein meal on ruminal fermentation and forestomach digestion in dairy cows. J. Dairy Sci. 80:1366-1373.

Robinson, P. H., and C. J. Sniffen. 1985. Forestomach and whole tract digestibility for lactating dairy cows as influenced by feeding frequency. J. Dairy Sci. 68:857-867.

Robinson, P. H., C. J. Sniffen, and P. J. V. Soest. 1985. Influence of level of feed intake on digestion and bacterial yield in the forestomachs of dairy cattle. Can. J. Anim. Sci. 65:437-444.

Saltelli, A., S. Tarantola, and K. P.-S. Chan. 1999. A quantitative model-independent method for global sensitivity analysis of model output. Technometrics 41:39-56.

Santos, K. A., M. D. Stern, and L. D. Satter. 1984. Protein degradation in the rumen and amino acid absorption in the small intestine of lactating dairy cattle fed various protein sources. J. Anim. Sci. $58: 244-255$.

Sarwar, M., J. L. Firkins, and M. L. Eastridge. 1991. Effect of replacing neutral detergent fiber of forage with soyhulls and corn gluten feed for dairy heifers. J. Dairy Sci. 74:1006-1017.

Satter, L. D., and L. L. Slyter. 1974. Effect of ammonia concentration of rumen microbial protein production in vitro. Br. J. Nutr. 32:199-208.

Schwab, C. G., C. K. Bozak, and N. L. Whitehouse. 1992a. Amino acid limitation and flow to duodenum at four stages of lactation. 1. Sequence of lysine and methionine limitation. J. Dairy Sci. 75:3486-3502.

Schwab, C. G., C. K. Bozak, N. L. Whitehouse, and V. M. Olson. 1992b. Amino acid limitation and flow to the duodenum at four stages of lactation. 2. Extent of lysine limitation. J. Dairy Sci. 75:3503-3518.

Seymour, W. M., C. E. Polan, and J. H. Herbein. 1992. In vivo degradation of protein in diets formulated for two degradabilities. J. Dairy Sci. 75:2447-2453.

Song, M. K., and J. J. Kennelly. 1989. Effect of ammoniated barley silage on ruminal fermentation, nitrogen supply to the small intestine, ruminal and whole tract digestion, and milk production of Holstein cows. J. Dairy Sci. 72:2981-2990.

St-Pierre, N. R. 2001. Invited review: Integrating quantitative findings from multiple studies using mixed model methodology. J. Dairy Sci. 84:741-755.
Stevens, C. E., and B. K. Stettler. 1966. Factors affecting the transport of volatile fatty acids across rumen epithelium. Am. J. Physiol. 210:365-372.

Stokes, S. R., W. H. Hoover, T. K. Miller, and R. Blauweikel. 1991. Ruminal digestion and microbial utilization of diets varying in type of carbohydrate and protein. J. Dairy Sci. 74:871-881.

Storm, A. C., M. D. Hanigan, and N. B. Kristensen. 2011. Effects of ruminal ammonia and butyrate concentrations on reticuloruminal epithelial blood flow and volatile fatty acid absorption kinetics under washed reticulorumen conditions in lactating dairy cows. J Dairy Sci. 94:3980-3994.

Storm, A. C., N. B. Kristensen, and M. D. Hanigan. 2012. A model of ruminal volatile fatty acid absorption kinetics and rumen epithelial blood flow in lactating Holstein cows. J. Dairy Sci. 95:2919-2934.

Tice, E. M., M. L. Eastridge, and J. L. Firkins. 1993. Raw soybeans and roasted soybeans of different particle sizes. 1. Digestibility and utilization by lactating cows. J. Dairy Sci. 76:224-235.

Van Soest, P. J. 1982. Nutritional Ecology of the Ruminant. O \& B Books Inc., Corvallis, OR.

Waltz, D. M., M. D. Stern, and D. J. Illg. 1989. Effect of ruminal protein degradation of blood meal and feather meal on the intestinal amino acid supply to lactating cows. J. Dairy Sci. 72:1509-1518.

Whitelaw, F. G., J. M. Eadie, L. A. Bruce, and W. J. Shand. 1984 Methane formation in faunated and ciliate-free cattle and its relationship with rumen volatile fatty acid proportions. Br. J. Nutr. 52:261-275.

Windschitl, P. M., and M. D. Stern. 1988. Evaluation of calcium lignosulfonate-treated soybean meal as a source of rumen protected protein for dairy cattle. J. Dairy Sci. 71:3310-3322.

Yang, W. Z., K. A. Beauchemin, K. M. Koenig, and L. M. Rode. 1997 Comparison of hull-less barley, barley, or corn for lactating cows: Effects on extent of digestion and milk production. J. Dairy Sci 80:2475-2486.

Yoon, I. K., and M. D. Stern. 1996. Effects of Saccharomyces cerevisiae and Aspergillus oryzae cultures on ruminal fermentation in dairy cows. J. Dairy Sci. 79:411-417.

Zerbini, E., C. E. Polan, and J. H. Herbein. 1988. Effect of dietary soybean meal and fish meal on protein digesta flow in Holstein cows during early and midlactation. J. Dairy Sci. 71:1248-1258.

Zhu, J. S., S. R. Stokes, and M. R. Murphy. 1997. Substitution of neutral detergent fiber from forage with neutral detergent fiber from by-products in the diets of lactating cows. J. Dairy Sci 80:2901-2906. 